\title{
Article \\ A Complete In Vitro Toxicological Assessment of the Biological Effects of Cerium Oxide Nanoparticles: From Acute Toxicity to Multi-Dose Subchronic Cytotoxicity Study
}

\author{
Adrián García-Salvador ${ }^{1}{ }^{(0}$, Alberto Katsumiti ${ }^{1}{ }^{(0}$, Elena Rojas ${ }^{2}$, Carol Aristimuño ${ }^{1}$, Mónica Betanzos ${ }^{1}{ }^{\circledR}$, \\ Marta Martínez-Moro ${ }^{2}$, Sergio E. Moya ${ }^{2}(D)$ and Felipe Goñi-de-Cerio ${ }^{1, *(D)}$ \\ 1 GAIKER Technology Centre, Basque Research and Technology Alliance (BRTA), 48170 Zamudio, Spain; \\ garciaad@gaiker.es (A.G.-S.); katsumiti@gaiker.es (A.K.); aristimuno@gaiker.es (C.A.); \\ betanzos@gaiker.es (M.B.) \\ 2 CIC BiomaGUNE, BRTA, 20014 Donostia-San Sebastián, Spain; erojas@cicbiomagune.es (E.R.); \\ mmartinez@cicbiomagune.es (M.M.-M.); smoya@cicbiomagune.es (S.E.M.) \\ * Correspondence: goni@gaiker.es; Tel.: +34-688-649-878
}

Citation: García-Salvador, A.; Katsumiti, A.; Rojas, E.; Aristimuño, C.; Betanzos, M.; Martínez-Moro, M.; Moya, S.E.; Goñi-de-Cerio, F. A Complete In Vitro Toxicological Assessment of the Biological Effects of Cerium Oxide Nanoparticles: From Acute Toxicity to Multi-Dose Subchronic Cytotoxicity Study. Nanomaterials 2021, 11, 1577. https://doi.org/10.3390/ nano11061577

Academic Editor:

Vanessa Valdiglesias

Received: 20 May 2021

Accepted: 14 June 2021

Published: 16 June 2021

Publisher's Note: MDPI stays neutral with regard to jurisdictional claims in published maps and institutional affiliations.

Copyright: (c) 2021 by the authors. Licensee MDPI, Basel, Switzerland. This article is an open access article distributed under the terms and conditions of the Creative Commons Attribution (CC BY) license (https:// creativecommons.org/licenses/by/ $4.0 /)$.

\begin{abstract}
Engineered nanomaterials (ENMs) are of significant relevance due to their unique properties, which have been exploited for widespread applications. Cerium oxide nanoparticles $\left(\mathrm{CeO}_{2}-\mathrm{NPs}\right)$ are one of most exploited ENM in the industry due to their excellent catalytic and multi-enzyme mimetic properties. Thus, the toxicological effects of these ENMs should be further studied. In this study, the acute and subchronic toxicity of $\mathrm{CeO}_{2}-\mathrm{NPs}$ were assessed. First, an in vitro multi-dose short-term $(24 \mathrm{~h})$ toxicological assessment was performed in three different cell lines: A549 and Calu3 were used to represented lung tissue and 3 T3 was used as an interstitial tissue model. After that, a sub-chronic toxicity assessment (90 days) of these NPs was carried out on a realistic and well-established reconstituted primary human airway epithelial model (MucilAir ${ }^{\mathrm{TM}}$ ), cultured at the Air-Liquid Interface (ALI), to study the long-term effects of these particles. Results showed minor toxicity of $\mathrm{CeO}_{2}$-NPs in acute exposures. However, in subchronic exposures, cytotoxic and inflammatory responses were observed in the human airway epithelial model after 60 days of exposure to $\mathrm{CeO}_{2}$-NPs. These results suggest that acute toxicity approaches may underestimate the toxicological effect of some ENMs, highlighting the need for subchronic toxicological studies in order to accurately assess the toxicity of ENM and their cumulative effects in organisms.
\end{abstract}

Keywords: Cerium oxide NPs; acute and subchronic toxicity; in vitro; pulmonary and interstitial cell lines; human airway epithelial model; air-liquid interface; aerosolized NPs

\section{Introduction}

In the last decades, the use of nanotechnology has revolutionized many biotechnological sectors [1]. Engineered nanomaterials (ENMs) possess unique physical, electrical, and chemical properties [2], which have been exploited for widespread applications in electronics, aerospace, medicinal drug delivery, medical devices, biosensors, engineering, bioengineering, food, and cosmetics [1-8]. The increasing use of ENMs and their consequent release into the environment [9-11] has raised concerns about their safety and their potential risks to human health [12-16].

Among these ENMs, cerium oxide nanoparticles $\left(\mathrm{CeO}_{2}-\mathrm{NPs}\right)$ are one of the most exploited ENMs. For instance, due to their autoregenerative cycle between two oxidation states, $\mathrm{Ce}^{+3}$ and $\mathrm{Ce}^{+4}[17,18], \mathrm{CeO}_{2}-\mathrm{NPs}$ have been used as promising antioxidant and anti-UV agents [19]. $\mathrm{CeO}_{2}-\mathrm{NPs}$ have also been used as fuel catalyst additives [20], in polish surface treatment, and in cosmetics and sunscreens [21]. More recently, $\mathrm{CeO}_{2}-\mathrm{NPs}_{\text {have }}$ been used as therapeutic agents to prevent blindness caused by light overexposure [22], to prevent age-related macular degeneration [23], and as anti-microbial agents by disrupting 
bacterial electron transport chain [24,25] and reducing the infectivity of certain viruses in vitro [26]. Despite their excellent catalytic and multi-enzyme mimetic properties [27], the potential toxicity of $\mathrm{CeO}_{2}-\mathrm{NPs}$ to different organisms raises concerns [28-30]. Thus, the toxic mechanisms of $\mathrm{CeO}_{2}$-NPs should be carefully and systematically investigated [27].

It has been reported that the main route of exposure to $\mathrm{CeO}_{2}-\mathrm{NPs}$ is through inhalation, e.g., during occupational exposure when manufacturing $\mathrm{CeO}_{2}-\mathrm{NP}$-based products $[31,32]$. Thus, the lung is the main target organ for toxic effects after airborne $\mathrm{CeO}_{2}-\mathrm{NPs}$ [31-35] exposure.

Although animal models have been traditionally used in inhalation toxicology research, animal welfare concerns and $3 R$ directrices encourage the use of alternative in vitro models for toxicological research [36-38]. In vitro models based on pulmonary cells represent excellent tools to study lung toxicity induced by exposure to ENMs. Immortalized or tumorigenic cell lines (A549, BEAS-2B, and Calu-3) are routinely used as monolayer models [39] or in co-culture with immune cells (e.g., differentiated THP-1) to study inflammatory responses induced by ENM exposure [40,41]. These in vitro models can be used both in submerged conditions or at the Air-Liquid Interface (ALI), which has been demonstrated to favor a better interaction between NPs and cells and has been considered physiologically more relevant for inhaled NPs research [32,40,42]. These models are considered useful tools for acute high-throughput screening of different air pollutants [42]. However, they are quite simplistic and do not represent an in vivo condition, since they are based on tumorigenic cells that lack inherent primary cell characteristics and do not reproduce the architecture of the lung tissue [42].

To overcome these limitations, 3D human airway epithelial models based on primary cells have already been used, as they better mimic the lung architecture and primary cells conserve original characteristics $[43,44]$. Currently, there are few commercially available human airway epithelial 3D models, EpiAirway ${ }^{\mathrm{TM}}$ from MatTek and MucilAir ${ }^{\mathrm{TM}}$ from Epithelix. MucilAir ${ }^{\mathrm{TM}}$ is a reconstituted primary human airway epithelial (PHAE) model from human nasal or bronchial biopsies [45] that can be maintained in culture conditions for up to a year, allowing long-term and repeated exposures [45]. Baxter et al. [46] have demonstrated the suitability of this model for long-term exposures to toxicants. Meldrum et al. [47] used the PHAE model to assess the mid-term (up to three weeks) cytotoxicity of $\mathrm{CeO}_{2}-\mathrm{NPs}$, showing that this 3D model may represent a more realistic model to predict the toxicity of inhaled particles than cell line monolayers, (which may overestimate particles' toxicity). To the best of our knowledge, subchronic (over two months) effects of repeated exposures to $\mathrm{CeO}_{2}$-NPs have not yet been assessed in 3D PHAE models.

Currently, different systems have been developed to allow subchronic repeated exposure to toxicants in vitro. One of the most commonly used devices is the Vitrocell Cloud (VITROCELL Systems GmbH, Waldkirch, Germany). This device was specifically designed for exposure in ALI through the nebulization of the toxicant in a controlled atmosphere, allowing high deposition rates of the toxicant as well as robustness of results and high reproducibility [48]. This device offers the possibility of performing in vitro exposures to NPs in a much more realistic scenario.

In this context, the aim of this study was to assess acute toxicity $(24 \mathrm{~h})$ of $\mathrm{CeO}_{2}-\mathrm{NPs}$ on monocultured pulmonary (A548 and Calu-3) and non-pulmonary (3T3) cell lines and subchronic toxicity (up to 90 days) of the same nanoparticles on the physiologically relevant PHAE model exposed at the ALI through Vitrocell Cloud nebulization. This study aims to contribute to a better understanding of the cascade of acute to subchronic cellular responses in cells exposed to $\mathrm{CeO}_{2}$-NPs.

\section{Materials and Methods}

\subsection{Synthesis and Characterization of $\mathrm{CeO}_{2}$ Nanoparticles (NPs)}

$\mathrm{CeO}_{2}$-NPs were synthesized following the conventional gel-sol process. Briefly, commercial cerium chloride (Sigma-Aldrich, 228931, St. Louis, MO, USA) was dissolved in deionized water $(0.5 \mathrm{M})$ and stirred at $400 \mathrm{rpm}$ for $1 \mathrm{~h}$ at $60^{\circ} \mathrm{C}$ in a thermostatic bath Then, ammonium hydroxide (0.5 M) (Sigma-Aldrich, 221228, St. Louis, MO, USA) was 
added to the cerium chloride solution and stirred at the same conditions mentioned before for $120 \mathrm{~min}$ to allow NPs formation. After that, the mixture was left for $22 \mathrm{~h}$ at room temperature and then centrifuged, washed with deionized water, and finally heated at $110{ }^{\circ} \mathrm{C}$ to evaporate the aqueous solvent and obtain NPs as powder.

The shape and size of $\mathrm{CeO}_{2}-\mathrm{NPs}$ were determined by Transmission Electron Microscopy (TEM-JEM-2100F UHR, JEOL Ltd., Akishima, Tokyo, Japan). Dry powdered $\mathrm{CeO}_{2}$-NPs $(25 \mu \mathrm{g} / \mathrm{mL})$ were placed onto conducting carbon-coated copper grids for examination at the TEM. X-ray photoelectron spectroscopy (XPS-SAGE HR 100, SPECS, Berlin, Germany) was used to confirm the elemental composition and chemical state of $\mathrm{CeO}_{2}-\mathrm{NPs}$.

A Zetasizer Nano ZS (Malvern Panalytical, Malvern, UK) was used to determine zeta potential and hydrodynamic size distribution through DLS analysis. The average size and polydispersity index (PDI) were determined according to ISO22412. The PDI scale was 0-1, with 0 representing a monodisperse state and 1 representing a polydisperse state. For the DLS analysis, $\mathrm{CeO}_{2}-\mathrm{NPs}(100 \mu \mathrm{g} / \mathrm{mL})$ were suspended in distilled water since, due to the presence of particulate materials, no reliable measurements could be done in NP samples suspended in cell culture media.

\subsection{Cell Culture}

For the acute experiments, the murine fibroblast 3T3 cell line (CRL-1658), the lung adenocarcinoma Calu-3 cell line (HTB-55), and the alveolar epithelial adenocarcinoma A549 cell line (CCL-185) were obtained from ATCC (Wesel, Germany). The cell lines were cultured in DMEM supplemented with 10\% fetal bovine serum (FBS) and 1\% penicillin and streptomycin (P/S) solution (Life Technologies, Carlsbad, CA, USA), according to the manufacturer's instructions. The culture medium was renewed every $2-3$ days and the cells were subcultured when they reached 70-90\% confluency.

For the subchronic experiments, fully differentiated PHAE models (MucilAir ${ }^{\mathrm{TM}}$ ) were obtained from Epithelix Sárl (Geneva, Switzerland). The PHAE models were maintained on 24-well Transwell ${ }^{\circledR}$ inserts with its own culture medium (Epithelix Sárl, Geneva, Switzerland; supplemented with $1 \%$ Amphotericin, $1 \% \mathrm{P} / \mathrm{S}$, and $0.5 \%$ gentamicin). Inserts had a diameter of $6.5 \mathrm{~mm}$, a growth area of $0.33 \mathrm{~cm}^{2}$, and a $0.4 \mu \mathrm{m}$ pore size. Upon receipt, the PHAE models were maintained in the culture medium for at least one week prior to performing the experiments. The culture medium was renewed every 2-3 days.

\subsection{Acute Exposures to $\mathrm{CeO}_{2}-\mathrm{NPS}$}

For acute exposures, 3T3, Calu-3, and A549 cell lines were seeded at $10^{4}$ cells/well in 96-well plates $\left(3 \times 10^{4}\right.$ cell $\left./ \mathrm{cm}^{2}\right)$ and incubated for $24 \mathrm{~h}$ to allow confluence. Then, the culture medium was replaced by a fresh medium containing different doses of $\mathrm{CeO}_{2}-\mathrm{NPs}$ $(10,100$ and $500 \mu \mathrm{g} / \mathrm{mL})$ and cells were exposed for $24 \mathrm{~h}$ prior to assess $\mathrm{CeO}_{2}-\mathrm{NPs}$ cytotoxic effects. Before conducting the in vitro exposures, cell-free assays were carried out in order to evaluate the potential interference of $\mathrm{CeO}_{2}-\mathrm{NPs}$ with the toxicity assays.

\subsection{Subchronic Exposures to $\mathrm{CeO}_{2}-\mathrm{NPS}$}

For subchronic exposures in ALI, 24-well Transwell ${ }^{\circledR}$ inserts (Corning, 3470, Kennebunk, ME, USA) containing the PHAE model were placed into a Vitrocell ${ }^{\circledR}$ Cloud exposure system (VITROCELL Systems, Waldkirch, Germany). This device is specifically designed for ALI exposure assays and consists of a 12-well chamber ( 8 for exposure, 1 integrated Quartz Crystal Microbalance (QCM) and 3 for control) coupled to a heating block to allow constant $37{ }^{\circ} \mathrm{C}$ temperature, and a nebulizer (Aeroneb Lab ${ }^{\circledR}$, Kent Scientific, Torrington, CT, USA) on the top of the chamber. This device generates an aerosolized cloud of nanoparticles that homogeneously precipitate onto the cells due to the generated flow dynamics (vortices) after single droplet sedimentation [49]. Airway epithelia were exposed every 2 weeks during 3 months to three sublethal concentrations of $\mathrm{CeO}_{2}-\mathrm{NPs}\left(100 \mu \mathrm{g} / \mathrm{cm}^{2}, 10 \mu \mathrm{g} / \mathrm{cm}^{2}\right.$ and $\left.1 \mu \mathrm{g} / \mathrm{cm}^{2}\right)$ in order to assess their subchronic effects. After each exposure, the Transwell ${ }^{\circledR}$ inserts were placed in a new 24-well plate and incubated with the culture medium. 


\subsection{Acute Cytotoxicity}

Briefly, after exposures, cell viability was assessed by incubating cells with a MTT solution $\left(0.4 \mathrm{mg} / \mathrm{mL}\right.$, Sigma-Aldrich, M2003-1G, St. Louis, MO, USA) for $2 \mathrm{~h}$ at $37^{\circ} \mathrm{C}, 5 \%$ $\mathrm{CO}_{2}$. After the incubation, the insoluble formazan crystals were extracted from the cells by adding DMSO (PanReac AppliChem, A3672, Barcelona, Spain) into the wells. Absorbance was quantified at a $540 \mathrm{~nm}$ wavelength in a spectrophotometer reader (Varioskan ${ }^{\mathrm{TM}}$ Lux, ThermoScientific, Waltham, MA, USA). Cell viability was expressed as percentage of viability respect to untreated control cells. $\mathrm{CdSO}_{4}$ (Sigma-Aldrich, 383082, St. Louis, MO, USA) was used as positive control.

Apoptosis and necrosis were evaluated in exposed and unexposed cells using the Annexin-V/PI assay through flow cytometry. During the early stages of apoptosis, phosphatidylserine (PS) present on the inner leaflet of the plasma membrane is translocated to the outer layer. During apoptosis the cell membrane remains intact, whereas during necrosis the cell becomes leaky and loses its integrity. Annexin-V (Invitrogen ${ }^{\mathrm{TM}}, \mathrm{A} 13201$, Waltham, MA, USA) is a sensitive probe to detect PS on the plasma membrane of apoptotic cells. Propidium iodide (PI, Sigma-Aldrich, P4170, St. Louis, MO, USA) is a probe for discriminating necrotic cells. After NP treatment, cells were harvested and washed with an Annexin-V Binding Buffer (10 mM HEPES, pH 7.4, $150 \mathrm{mM} \mathrm{NaCl}, 5 \mathrm{mM} \mathrm{KCl}, 1 \mathrm{mM} \mathrm{MgCl} 2$ and $1.8 \mathrm{mM} \mathrm{CaCl}_{2}$, Sigma-Aldrich, St. Louis, MO, USA) and incubated with Annexin-V ( $5 \mu \mathrm{L} / 100 \mu \mathrm{L}$ of cell suspension), in darkness for $30 \mathrm{~min}$ at room temperature. Then, the cells were washed and incubated with PI $(1 \mu \mathrm{L} / 100 \mu \mathrm{L}$ of cell suspension). After that, the cells were immediately analyzed in a FC-500 two laser flow cytometer (Beckman Coulter, Brea, CA, USA). Doxorubicin treated cells were used as positive control for Annexin-V or PI and non-treated cells as negative control.

ROS production was detected using the DCFH-DA dye (Sigma-Aldrich, D6883, St. Louis, MO, USA). DCFH-DA is a stable non-fluorescent, cell permeable compound that is converted to DCFH by intracellular esterases and trapped inside the cells. DCFH is then converted into the highly fluorescent $2^{\prime}, 7^{\prime}$ dichlorofluorescein (DCF) by intracellular ROS and, upon excitation at $488 \mathrm{~nm}$, emits green fluorescence proportional to the intracellular ROS levels. After treatment, the cells were harvested, washed with PBS, and incubated with DCFH-DA $(5 \mu \mathrm{M})$ at $37^{\circ} \mathrm{C}$ for $30 \mathrm{~min}$ in darkness. Cells were then washed, centrifuged, resuspended in PBS, and kept on ice for an immediate detection by flow cytometry using the same flow cytometer mentioned before. Doxorubicin (Sigma-Aldrich, D-1515, St. Louis, MO, USA) was used as the positive control.

\subsection{Suchronic Effects}

The effects of $\mathrm{CeO}_{2}-\mathrm{NPs}$ treatment on the pulmonary barrier integrity were evaluated by measuring the transepithelial electrical resistance (TEER) of the reconstituted 3D human airway epithelia according to the manufacturer's instructions. Resistance was measured using an Epithelial Voltohmmeter (EVOM2) coupled to a STX2 chopstick electrode (World precision instruments, Sarasota, FL, USA). TEER readings were determined by subtracting the mean resistance of three inserts without cells (blank) from the recorded resistance of the airway epithelium, and subsequently multiplying the resulting value by the effective membrane surface area of the insert and expressing the results as $\Omega^{*} \mathrm{~cm}^{2}$. As airway epithelia were cultured in ALI, $200 \mu \mathrm{L}$ of saline solution $\left(0.9 \% \mathrm{NaCl}, 1.25 \mathrm{mM} \mathrm{CaCl}_{2}\right.$ and 10 mM HEPES, Sigma-Aldrich, St. Louis, MO, USA) was apically added on the monolayers right before TEER measurements and then discarded at the end of the readings. TEER readings were determined every 2 days for 6 months.

The subchronic effects of $\mathrm{CeO}_{2}-\mathrm{NP}$ treatment on the cell viability of reconstituted 3D human airway epithelia were measured by employing the resazurin reduction method [50]. Briefly, inserts containing airway epithelia were washed with PBS and incubated with resazurin (6 $\mu \mathrm{M}$, Sigma-Aldrich, R-7017, St. Louis, MO, USA) for $1 \mathrm{~h}$ at $37^{\circ} \mathrm{C}$. After incubation, samples were taken from each insert and fluorescence was read at $\lambda_{\mathrm{ex}}=530 \mathrm{~nm}$ and $\lambda_{\mathrm{em}}=590 \mathrm{~nm}$ in a microplate reader (Varioskan Lux, ThermoFisher Scientific, Waltham, 
MA, USA). Viability was expressed as percentage of viability with respect to untreated control cells. Resazurin assay was determined every 10 days for 3 months.

The effect of $\mathrm{CeO}_{2}-\mathrm{NP}$ treatment on the plasma membrane integrity was measured employing the LDH test CytoTox $96^{\circledR}$ Non-Radioactive Cytotoxicity Assay kit, according to the manufacturer's instructions (Promega, G1780, Madison, WI, USA). Results were expressed as percentage of damaged cells with respect to untreated control cells. LDH release was measured every 2 weeks for 3 months. Absorbance was read at $\lambda=490 \mathrm{~nm}$ in a microplate reader (Varioskan Lux, ThermoFisher Scientific, Waltham, MA, USA).

The effects of $\mathrm{CeO}_{2}-\mathrm{NP}$ treatment on the extra-cellular release of two inflammatory cytokines (IL-1 $\beta$ and TNF- $\alpha$ ) was measured using commercially available ELISA kits (Invitrogen ${ }^{\mathrm{TM}}$ KHC3013 and KHC0012, respectively, Waltham, MA, USA), according to the manufacturer's instructions. IL-1 $\beta$ y TNF- $\alpha$ expression were assessed in the conditioned medium after NP exposure. Results were expressed as $\mathrm{pg} / \mathrm{mL}$. Absorbance was read at $\lambda=450 \mathrm{~nm}$ in a microplate reader (Varioskan Lux, ThermoFisher Scientific, Waltham, MA, USA).

\subsection{Statistical Analysis}

In all assays, data were presented as means \pm standard deviation. Normality of the data was confirmed by the Kolmogorov-Smirnoff test and the homogeneity of the variances by Levene's test. Differences among groups were assessed by ANOVA test followed by a Bonferroni-Dunn post-hoc test. A $p$-value $\leq 0.05$ was considered statistically significant. All analysis were performed using the Minitab version 16 statistic software (State Collage, PA, USA).

\section{Results}

\subsection{Physicochemical Characterization of $\mathrm{CeO}_{2}-\mathrm{NPS}$}

$\mathrm{CeO}_{2}$ particles morphology and size distribution were determined by TEM. According to the TEM analysis, $\mathrm{CeO}_{2}$-NPs showed irregular shape with particles ranging from 4 to $64 \mathrm{~nm}$ (Figure 1) and a mean size of $13.04 \mathrm{~nm} \pm 12.13$ (Figure 2). Element analysis confirmed that particles were constituted by $21.5 \%$ Cerium and $78.5 \%$ Oxygen. No contaminants $(>0.1-0.5 \%)$ were found (Figure 3).

According to the DLS analysis, $\mathrm{CeO}_{2}-\mathrm{NPs}$ showed a monomodal dispersion in water (Figure 4), suggesting a homogeneous distribution. The retrieved size of particles in suspension was $44.13 \mathrm{~nm}$, higher than the value obtained by TEM, indicating a possible particles aggregation. The zeta potential value of suspended particles was $+36.16 \mathrm{mV}$, indicating a stable dispersion.

\subsection{Acute Cytotoxicty}

According to the MTT assay, $\mathrm{CeO}_{2}-\mathrm{NPs}$ were not cytotoxic to A549, Calu-3, and 3T3 cell lines at the tested concentrations (Figure 5). $\mathrm{CdSO}_{4}$ (used as the positive control) significantly decreased cell viability $(p<0.05$, Figure 5$)$.

The percentage of positive cells for Annexin- $\mathrm{V}$ and PI markers in untreated and $\mathrm{CeO}_{2}$-NPs treated cells are shown in Figures 6 and 7, respectively. According to the results, a significant increment in the percentage of apoptotic cells (Annexin- $\mathrm{V}$ positive/PI negative) with respect to control cells was found in $3 \mathrm{~T} 3$ cells treated with $0.5 \mathrm{mg} / \mathrm{mL}$ of $\mathrm{CeO}_{2}$-NPs $(p<0.05)$. A significant increase was also observed in the percentage of PI positive cells (necrotic cells) in all treated cell lines at $500 \mu \mathrm{g} / \mathrm{mL}(p<0.05)$. The positive control Doxorubicin induced a significant increase of apoptosis and necrosis with respect to untreated cells in the three cell lines $(p<0.05)$. 

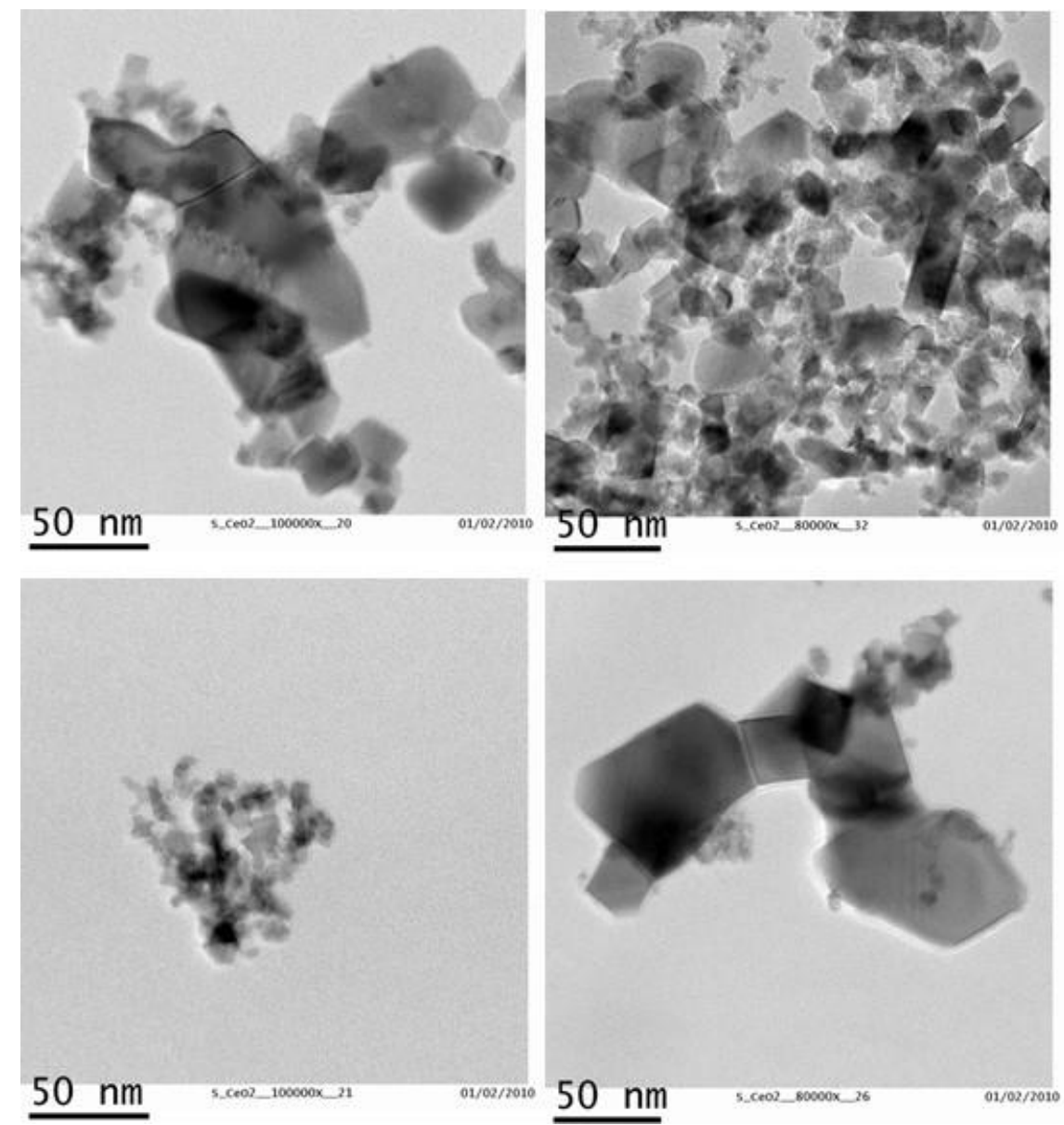

Figure 1. TEM images showing $\mathrm{CeO}_{2}$-NPs.

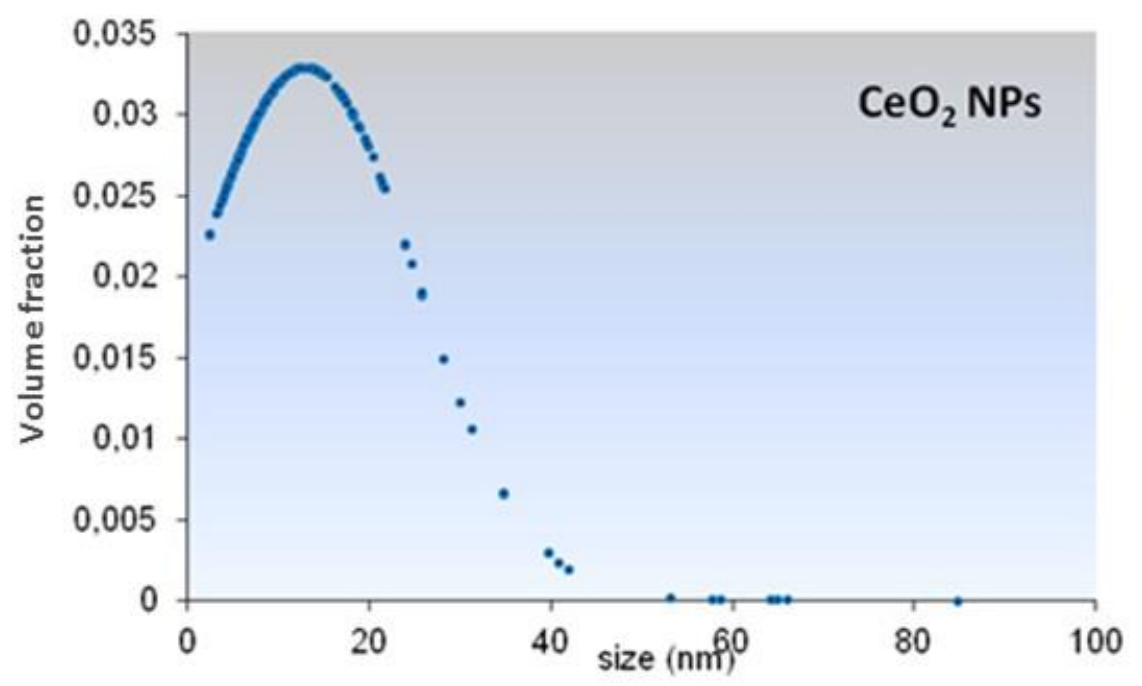

Figure 2. Size distribution of $\mathrm{CeO}_{2}-\mathrm{NPs}$. 


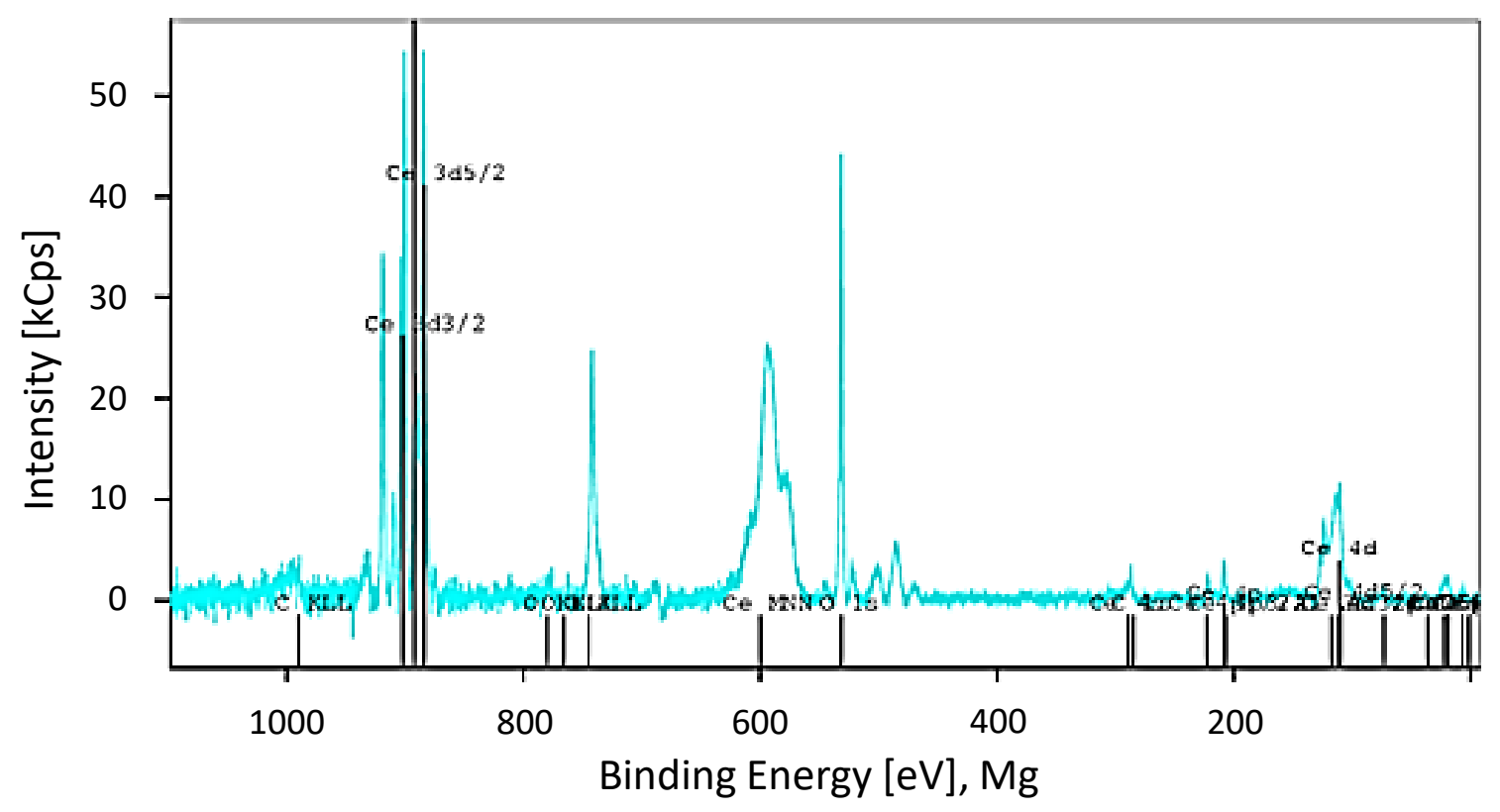

Figure 3. XPS spectra of $\mathrm{Ce}$ from $\mathrm{CeO}_{2}-\mathrm{NPs}$.

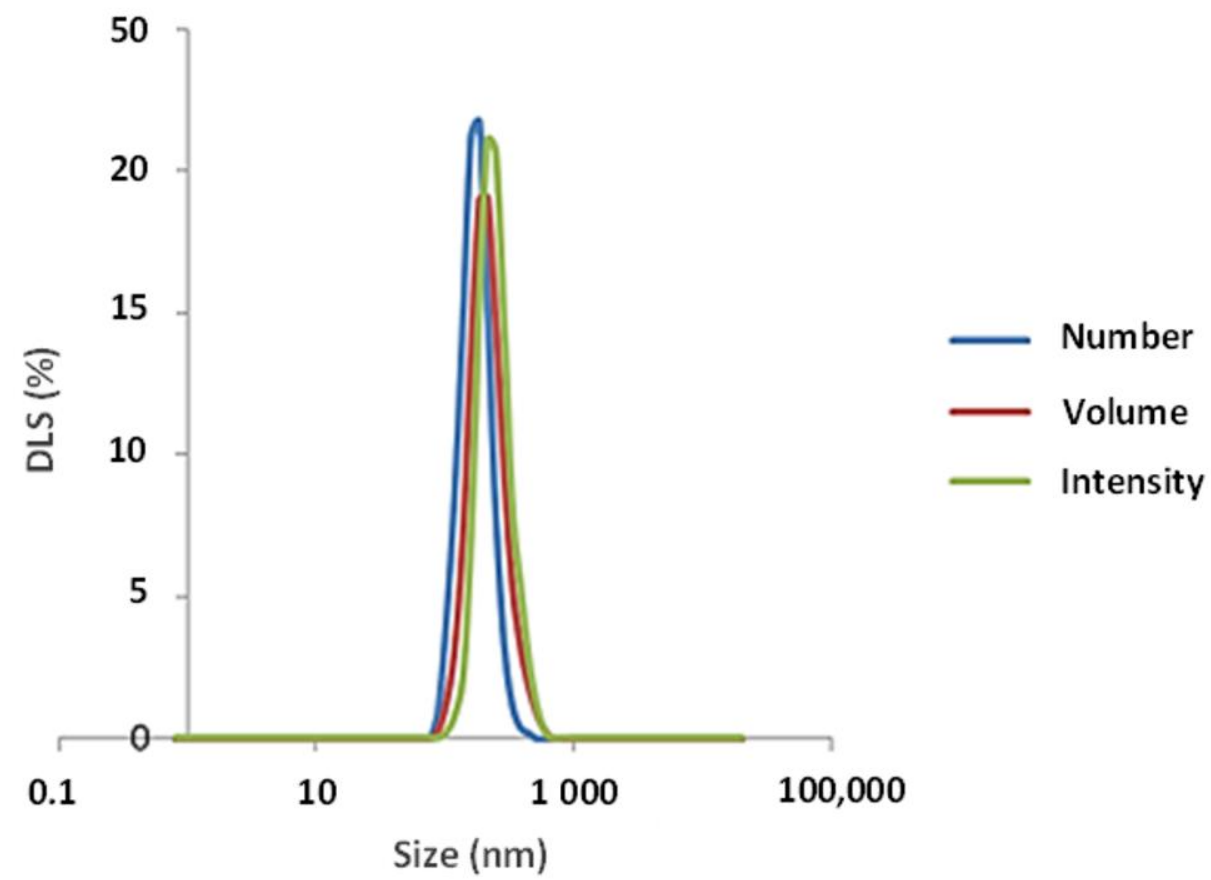

Figure 4. Hydrodynamic size distribution of $\mathrm{CeO}_{2}-\mathrm{NPs}$ suspended in water. 


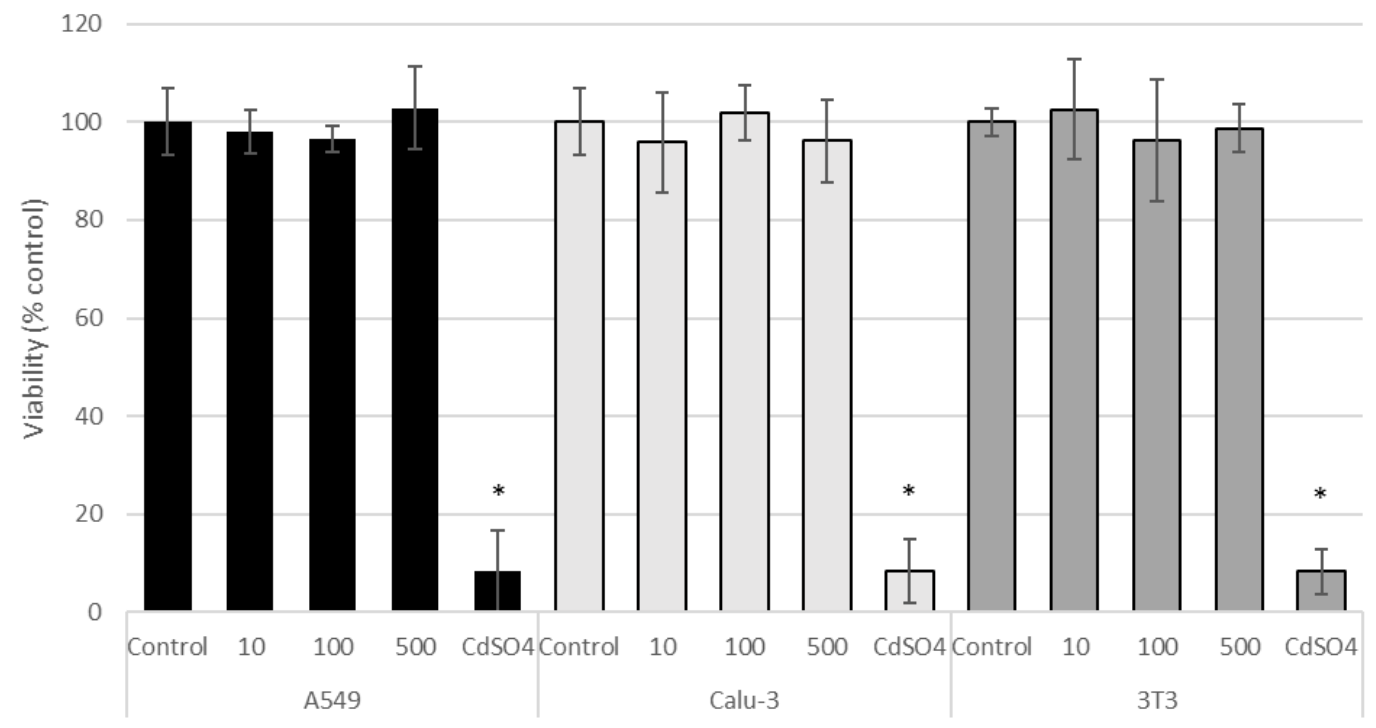

Figure 5. Cell viability (MTT assay) of control A549, Calu-3, and $3 \mathrm{~T} 3$ cells, and of cells exposed for $24 \mathrm{~h}$ to $\mathrm{CeO} 2-\mathrm{NPs}_{2}(10$, 100 , and $500 \mu \mathrm{g} / \mathrm{mL}$ ). Results are expressed as means \pm SD of six replicates per tested condition and three independent assays $(n=18)$. Asterisks indicate significant differences with respect to the untreated control cells $(p<0.05)$.

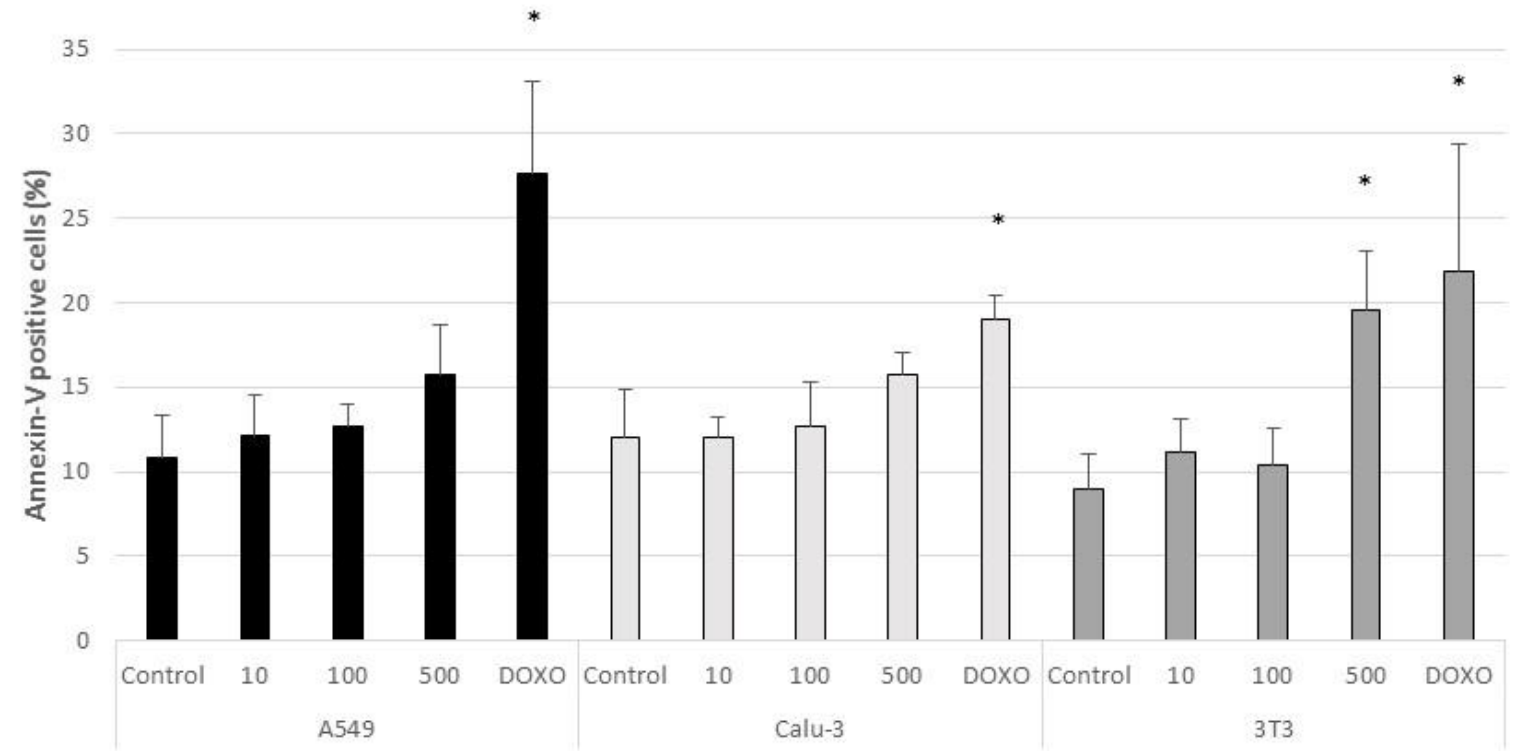

Figure 6. Apoptosis in control A549, Calu-3, and $3 \mathrm{~T} 3$ cells and in cells exposed for $24 \mathrm{~h}$ to $\mathrm{CeO}_{2}-\mathrm{NPs}(10,100$, and $500 \mu \mathrm{g} / \mathrm{mL}$ ), and to the positive control Doxorubicin. Results are expressed as means \pm SD of six replicates per tested condition and three independent assays $(n=18)$. Asterisks indicate significant differences with respect to the untreated control cells $(p<0.05)$. 


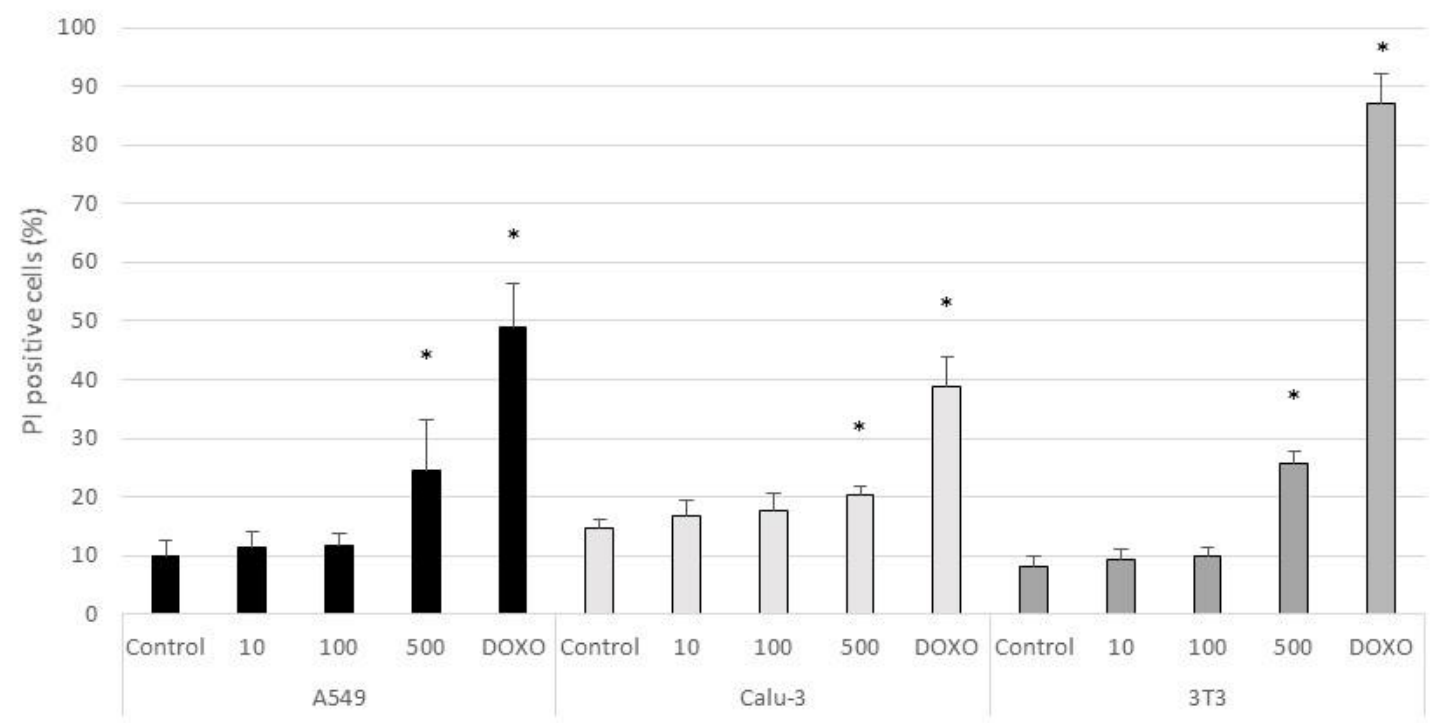

Figure 7. Necrosis in control A549, Calu-3, and $3 \mathrm{~T} 3$ cells and in cells exposed for $24 \mathrm{~h}$ to $\mathrm{CeO}_{2}-\mathrm{NPs}_{\mathrm{s}}(10,100$, and $500 \mu \mathrm{g} / \mathrm{mL})$, and to the positive control Doxorubicin. Results are expressed as means \pm SD of six replicates per tested condition and three independent assays $(n=18)$. Asterisks indicate significant differences with respect to the untreated control cells $(p<0.05)$.

At tested concentrations, $\mathrm{CeO}_{2}$-NPs did not induce ROS production in Calu-3 cells (Figure 8). On the other hand, there was a significant increment in ROS production in A549 and 3T3 cells exposed to the highest dose assayed $(500 \mu \mathrm{g} / \mathrm{mL})$ with respect to untreated control cells $(p<0.05)(24.48 \pm 4.64 \%$ in A549 cells and $28.85 \pm 6.06 \%$ in 3 T3 cells) (Figure 8). A significant increase in ROS production was also observed in the three cell lines treated with the positive control Doxorubicin $(p<0.005)(49.41 \pm 6.35 \%$ in A459 cells; $51.08 \pm 15.34 \%$ in Calu-3 cells and $99.71 \pm 0.22 \%$ in 3 T3 cells) (Figure 8 ).

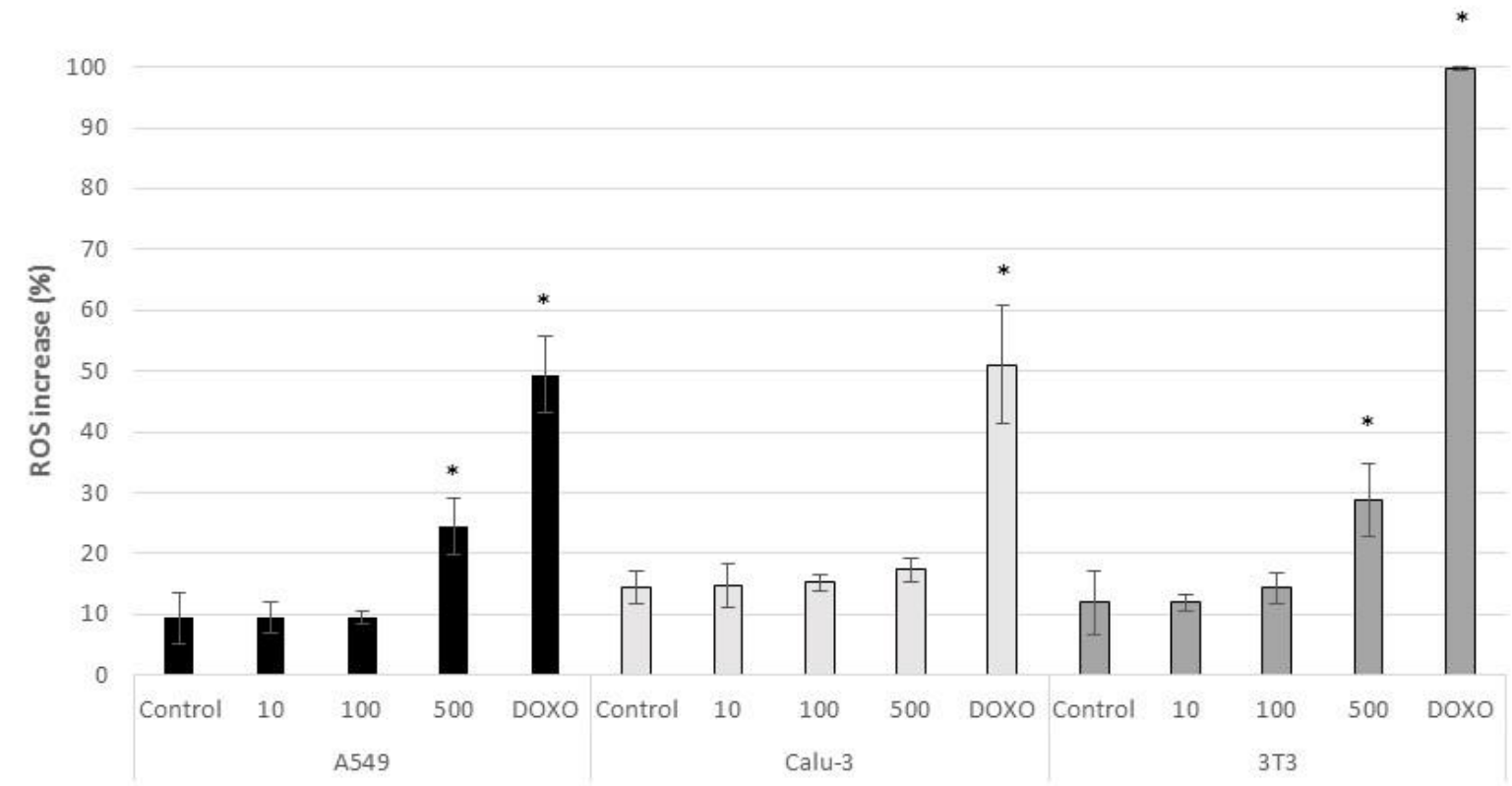

Figure 8. ROS production in control A549, Calu-3, and 3T3 cells and in cells exposed for $24 \mathrm{~h}$ to $\mathrm{CeO}_{2}-\mathrm{NPs}$ (10, 100, and $500 \mu \mathrm{g} / \mathrm{mL}$ ), and to the positive control Doxorubicin. Results are expressed as means \pm SD of six replicates per tested condition and three independent assays $(n=18)$. Asterisks indicate significant differences with respect to the untreated control cells $(p<0.05)$. 


\subsection{Subchronic Effects}

According to the results, TEER values ranged from $985 \pm 148.79$ to $2319.4 \pm 292.95 \Omega^{*} \mathrm{~cm}^{2}$, in all treated groups and for control cells between the day 0 and the day 90 of culture. No significant differences were observed among the different groups (Figure 9).

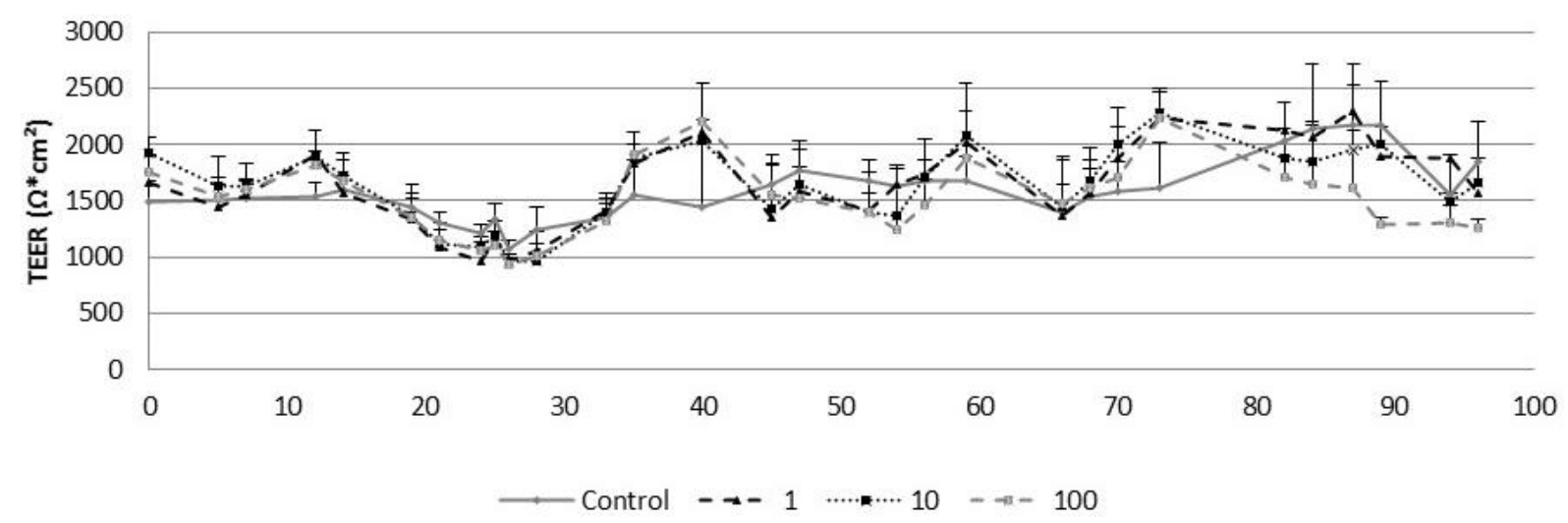

Figure 9. TEER values obtained in the control airway epithelia and in the airway epithelia exposed for three months to different concentrations of $\mathrm{CeO}_{2}-\mathrm{NPs}\left(1,10\right.$, and $\left.100 \mu \mathrm{g} / \mathrm{cm}^{2}\right)$. Exposures were performed every two weeks for three months. Results are expressed as means \pm SD of five replicates per tested condition and one assay $(n=5)$.

According to the results obtained in the resazurin assay, $\mathrm{CeO}_{2}-\mathrm{NPs}$ did not decrease the cell viability of airway epithelia during the first weeks (70 days) of exposure (Figure 10). However, after 80 days of treatment, $\mathrm{CeO}_{2}$-NPs significantly decreased the viability of airway epithelia exposed to the highest dose $\left(100 \mu \mathrm{g} / \mathrm{cm}^{2}\right)$ (day $80: 62.70 \pm 8.32 \%$ and day 90: $75.5 \pm 13.31 \%)$. There was no effect in cells exposed to lower doses throughout the study (Figure 10).

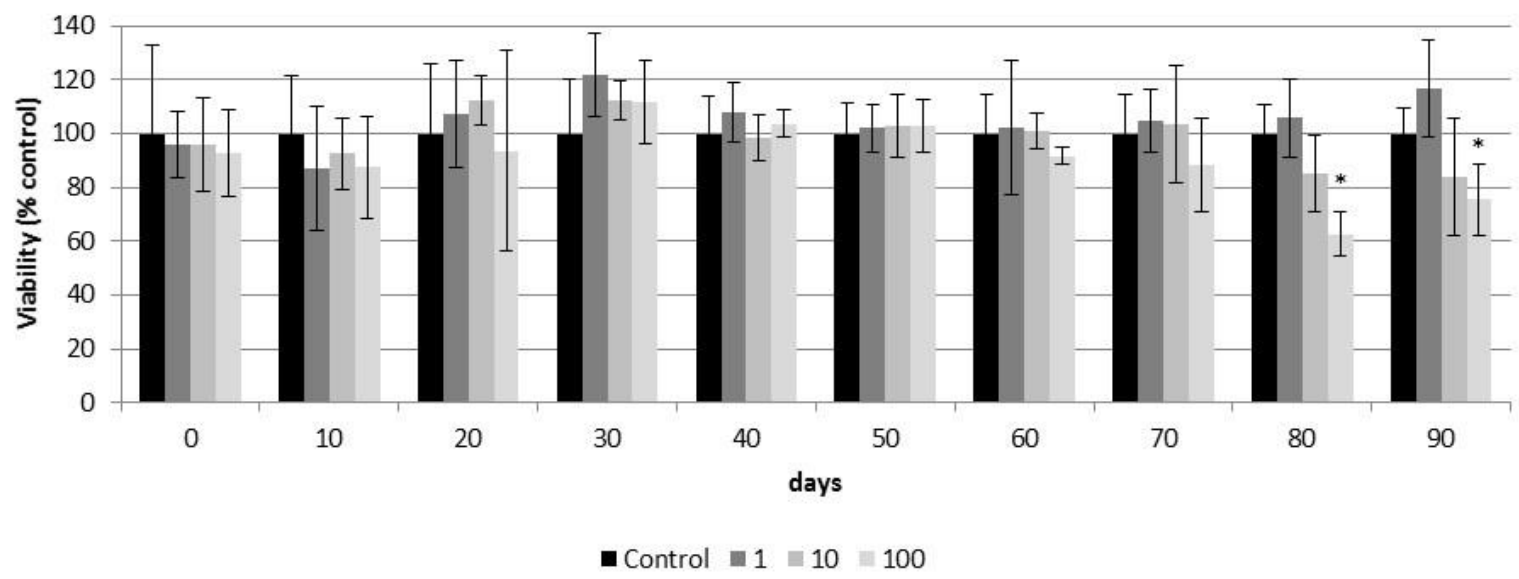

Figure 10. Viability (resazurin assay) of control airway epithelia and airway epithelia exposed for 90 days to different concentrations of $\mathrm{CeO}_{2}-\mathrm{NPs}\left(1,10\right.$, and $\left.100 \mu \mathrm{g} / \mathrm{cm}^{2}\right)$. Exposures were performed every two weeks for three months. Results are expressed as means $\pm \mathrm{SD}$ of five replicates per tested condition and one assay $(n=5)$. Asterisks indicate significant differences with respect to the untreated control cells $(p<0.05)$.

Based on the $\mathrm{LDH}$ test, $\mathrm{CeO}_{2}$-NPs did not affect the plasma membrane integrity of reconstituted 3D PHAE model during the first weeks (75 days) of exposure (Figure 11). At day 90 of culture, a significant increase in the LDH released was observed in airway epithelia exposed to $100 \mathrm{\mu g} / \mathrm{cm}^{2}$ of $\mathrm{CeO}_{2}-\mathrm{NPs}(121.65 \pm 2.10 \%)$ with respect to the untreated control group (Figure 11). 


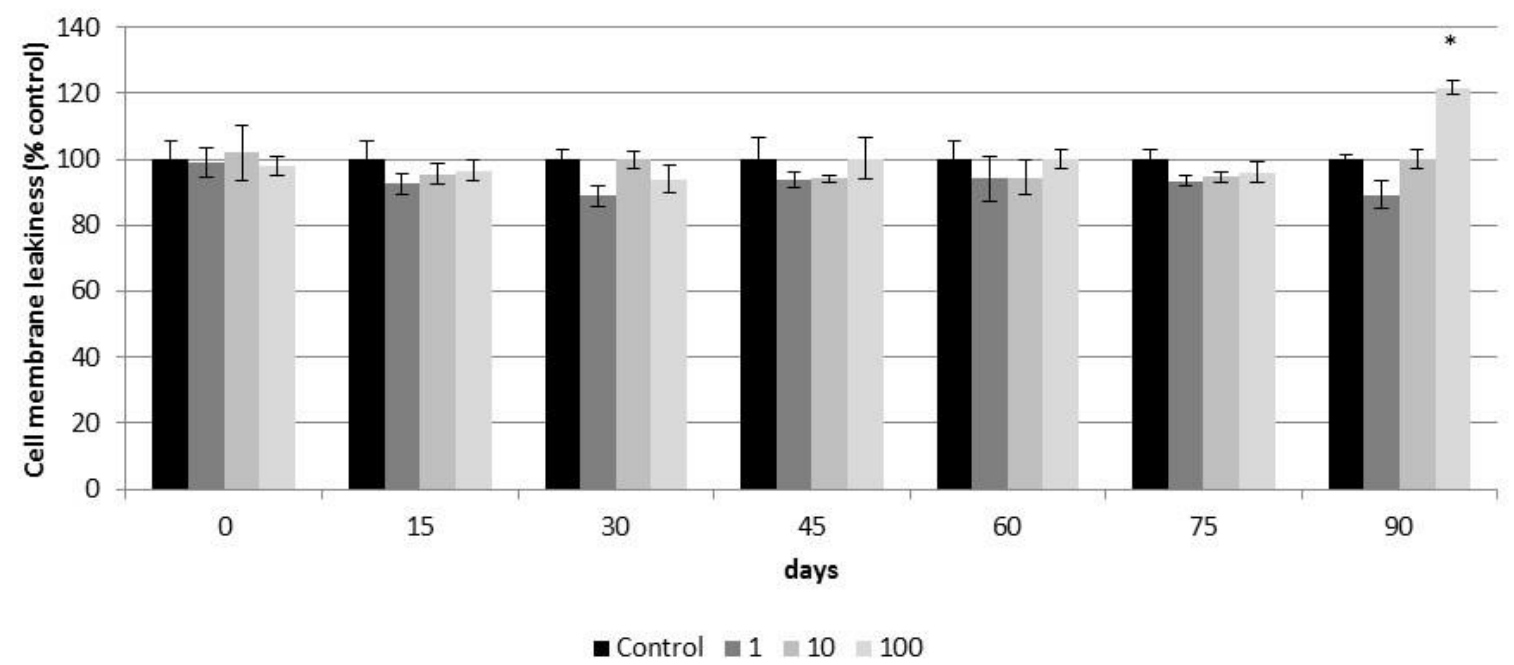

Figure 11. Cell membrane integrity (LDH test) of control airway epithelia and airway epithelia exposed for 90 days to different concentrations of $\mathrm{CeO}_{2}$-NPs $\left(1,10\right.$, and $\left.100 \mu \mathrm{g} / \mathrm{cm}^{2}\right)$. Exposures were performed every two weeks for three months. Results are expressed as means \pm SD of five replicates per tested condition and one assay $(n=5)$. The asterisk indicates significant differences with respect to the untreated control cells $(p<0.05)$.

A significant increase in TNF- $\alpha$ production was observed in airway epithelia after 60 and 75 days of exposure to $100 \mu \mathrm{g} / \mathrm{cm}^{2}$ of $\mathrm{CeO}_{2}-\mathrm{NPs}(28 \pm 0.39 \mathrm{pg} / \mathrm{mL}$ and $58.68 \pm 9.36 \mathrm{pg} / \mathrm{mL}$ respectively) (Figure 12). This increase was not observed at day 90 of exposure. Lower concentrations of $\mathrm{CeO}_{2}-\mathrm{NPs}$ did not induce TNF- $\alpha$ production in airway epithelia for the 90 days of exposure (Figure 12). Similarly, a significant increase in IL-1 $\beta$ secretion was observed in airway epithelia exposed for 75 days to $100 \mu \mathrm{g} / \mathrm{cm}^{2}$ of $\mathrm{CeO}_{2}-\mathrm{NPs}(43.11 \pm 9.27 \mathrm{pg} / \mathrm{mL})$ and this increase was not observed at the day 90 of exposure (Figure 13). As for TNF- $\alpha$ production, lower concentrations of $\mathrm{CeO}_{2}-\mathrm{NPs}$ did not induce IL- $1 \beta$ secretion for the 90 days of exposure (Figure 13)

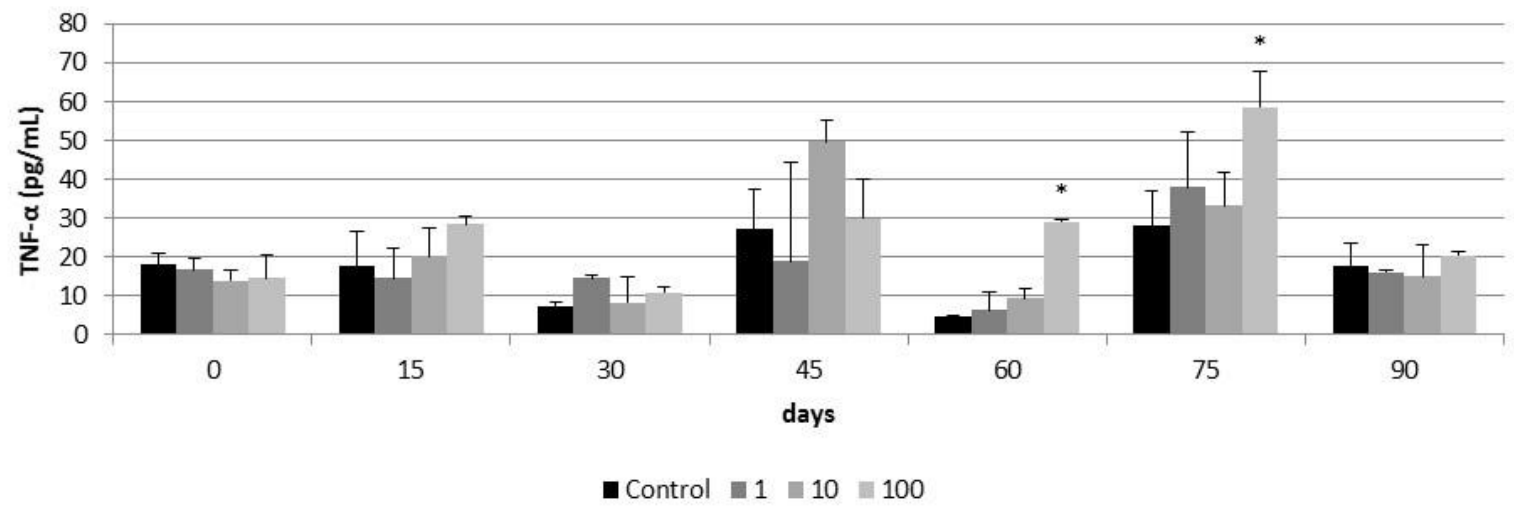

Figure 12. TNF- $\alpha$ release in control airway epithelia and in airway epithelia exposed for 90 days to different concentrations of $\mathrm{CeO}_{2}$-NPs $\left(1,10\right.$, and $100 \mu \mathrm{g} / \mathrm{cm}^{2}$ ). Exposures were performed every two weeks for three months. Results are expressed as means \pm SD of five replicates per tested condition and one assay $(n=5)$. Asterisks indicate significant differences with respect to the untreated control cells $(p<0.05)$. 


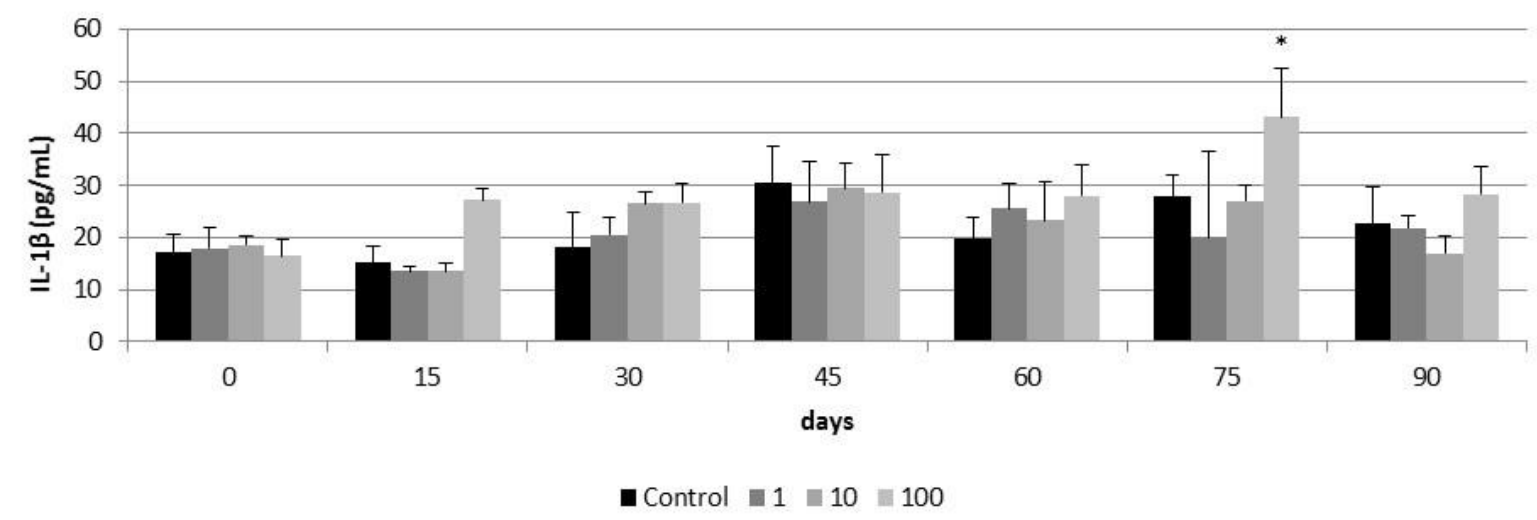

Figure 13. IL-1 $\beta$ release in control airway epithelia and in airway epithelia exposed for 90 days to different concentrations of $\mathrm{CeO}_{2}$-NPs $\left(1,10\right.$, and $\left.100 \mu \mathrm{g} / \mathrm{cm}^{2}\right)$. Exposures were performed every two weeks for three months. Results are expressed as means \pm SD of five replicates per tested condition and one assay $(n=5)$. The asterisk indicates significant differences with respect to the untreated control cells $(p<0.05)$.

\section{Discussion}

As biological responses of lung cells exposed to nanoparticles depend not only on the exposure dose but also on the intrinsic properties of the NPs (e.g., size, shape, chemical composition, surface reactivity, and degree of aggregation), NPs must always be characterized before performing the toxicity assays [51-53] and, whenever possible the homogeneity of different batches must be ensured [54].

According to the characterization of our in-house manufactured $\mathrm{CeO}_{2}-\mathrm{NPs}$, TEM analysis showed that particles ranged from 4 to $64 \mathrm{~nm}$ (mean size $=13.04 \mathrm{~nm}$ ) and displayed an irregular shape. Once suspended in distilled water, DLS analysis showed particles with a hydrodynamic size of about $44 \mathrm{~nm}$, with a monomodal and homogeneous distribution and high stability in the medium. The higher mean size obtained by DLS may be due to an overestimation of particle size, caused by a slight aggregation of the particles in distilled water by shear forces, as reported by other authors $[55,56]$. In complex media, such as a cell culture medium, aggregation might be higher due to the presence of organic molecules (e.g., amino acids). This aggregation is expected to affect the uptake and consequent toxicity of $\mathrm{CeO}_{2}$-NPs.

In the present study $\mathrm{CeO}_{2}$-NPs were not highly cytotoxic at tested concentrations but did induce cellular responses in both acute and subchronic exposures. In the acute approach, despite the absence of cytotoxicity in the MTT assay, results obtained in the more sensitive Annexin V-PI assay showed a significantly higher percentage of PI and Annexin $\mathrm{V}$ positive cells in the $3 \mathrm{~T} 3$ cell line exposed to $500 \mu \mathrm{g} / \mathrm{mL}$ of $\mathrm{CeO}_{2}-\mathrm{NPs}$, indicating that these NPs induce apoptotic and necrotic processes. Furthermore, a significant increase in ROS production was observed in both the A549 and $3 \mathrm{~T} 3$ cell lines exposed to $\mathrm{CeO}_{2}-$ $\mathrm{NPs}$ at the same concentration. Although $\mathrm{CeO}_{2}-\mathrm{NPs}$ are known to possess excellent antioxidant properties by scavenging free radicals, it has already been reported that they can also induce ROS production [24]. The exact mechanism by which they exhibit this oxidizing/antioxidant activity is not clearly understood, but it seems that the reason for this dual activity lies on the fact that if $\mathrm{CeO}_{2}-\mathrm{NPs}$ are strongly affected by the $\mathrm{pH}$ of the solution, then these particles can act as oxidizing or antioxidants agents [24,57]. Similar mechanisms of toxicity were reported by other authors, albeit at lower concentrations [58]. For instance, Mittal and Pandey [58] reported a concentration and time-dependent decrease of A549 viability exposed to $\mathrm{CeO}_{2}-\mathrm{NPs}$ at concentrations starting at $10 \mu \mathrm{g} / \mathrm{mL}$. At the same concentrations, $\mathrm{CeO}_{2}$-NPs caused a concentration and time-dependent decrease in mitochondrial membrane potential and an increase in ROS production in the same cell model. At a lower concentration $(1 \mu \mathrm{g} / \mathrm{mL})$, authors reported an increase in apoptosis. The lower cytotoxicity of our $\mathrm{CeO}_{2}$-NPs may be related to their physical-chemical properties. Particles used by Mittal and Pandey [58] were negatively charge $(-13.7 \mathrm{mV})$, whereas 
our particles were positively charged (+36.16). It was previously reported that negatively charged $\mathrm{CeO}_{2}-\mathrm{NPs}$ tend to internalize more easily than positively or neutral charged $\mathrm{CeO}_{2}-$ NPs in cancer cell lines [54]. Thus, positively charged particles are expected to induce lower toxic effects on these cells.

Although acute toxicity studies in cell monolayers provide valuable information about the toxic effect of NPs, there is a need to use more realistic in vitro models that could better mimic lung tissue and exposure conditions and, allow for long-term subchronic and chronic evaluations [59]. Thus, the use of robust models such as PHAE models is highly encouraged. This three-dimensional model is a fully differentiated and functional human respiratory model that conserves respiratory epithelial properties such as metabolic activity, mucus production, and ciliary movement and has a life-span of up to one year $[42,45,60,61]$. In addition it was demonstrated through a study combining weight of evidence from proteomics, gene expression, and protein activity that this system is physiologically more suitable for repeated exposures to toxicants [46]. Therefore, after completing the assessment of the acute $(24 \mathrm{~h})$ cytotoxicity of $\mathrm{CeO}_{2}-\mathrm{NPs}$, we proceeded to study the subchronic (3 months) cytotoxicity of repeated exposures to sublethal doses of $\mathrm{CeO}_{2}-\mathrm{NPs}$ in the 3D PHAE model.

In order to reproduce a more realistic exposure scenario, maintaining the conditions of temperature and humidity in physiological levels needed in the cell culture, the Vitrocell Cloud system coupled to an AeroNeb Lab nebulizer was used for exposure of the cells to $\mathrm{CeO}_{2}-\mathrm{NPs}$. Other authors have already demonstrated the suitability of this system to reproduce an inhalation scenario and have demonstrated that A549 cells in vitro are able to uptake similar concentrations of $\mathrm{CeO}_{2}$-NPs as those taken up in vivo [62]. During the exposures, the Vitrocell Cloud system produced a very homogeneous deposition of $\mathrm{CeO}_{2}$-NPs onto the cells similar to previous studies [48]. Thus, a multidose experiment was performed applying three sublethal doses of $\mathrm{CeO}_{2}-\mathrm{NPs}\left(1,10\right.$, and $\left.100 \mu \mathrm{g} / \mathrm{cm}^{2}\right)$ on the apical inserts every two weeks for three months. After three months of exposure to $\mathrm{CeO}_{2}-$ $\mathrm{NPs}$, the barrier integrity of the reconstituted PHAE model showed no detrimental effects, as evidenced in the TEER measurement. TEER values underwent variations throughout the three months (ranging $309-760 \Omega^{*} \mathrm{~cm}^{2}$ ), due to the constant cellular regeneration as a result of a differentiated and metabolically active epithelium composed of several cell types $[44,63]$. Despite the changes in cell cohesion values, TEER values always exceeded $300 \Omega^{*} \mathrm{~cm}^{2}$ during the exposure time. These values agree with others studies where researchers reported TEER values around $600 \Omega^{*} \mathrm{~cm}^{2}[61,64]$, or lower $[65,66]$.

Based on the cell viability resazurin assay, exposure of up to 70 days to 1 to $100 \mu \mathrm{g} / \mathrm{cm}^{2}$ of $\mathrm{CeO}_{2}$-NPs showed no cytotoxic effects on the PHAE model. Similarly, up to 75 days exposure to the same concentrations of $\mathrm{CeO}_{2}-\mathrm{NPs}$ did not affect the plasma membrane integrity of the PHAE model. However, after 80 days of exposure to $100 \mu \mathrm{g} / \mathrm{cm}^{2}$ of $\mathrm{CeO}_{2}-$ NPs, the viability of the PHAE model started to decrease. After 90 days of exposure to the same concentration of $\mathrm{CeO}_{2}-\mathrm{NPs}$, the integrity of the plasma membrane of the PHAE model was compromised. The late toxic response observed in the PHAE model could be related to the protective effect of mucociliary clearance. Mucociliary clearance is a defense mechanism that protects the pulmonary system from harmful inhaled agents, including NPs. This was already reported by other authors [67] who compared the toxicity of $\mathrm{CeO}_{2}-\mathrm{NPs}$ on isolated Calu3 and A549 cells with the toxicity of the same particles on a PHAE model and reported that toxicity was lower in the later system, possibly due to the mucociliary defense present in the 3D model. This could indicate that the cell lines did not accurately reflect the toxic effect of the nanoparticles because they lacked the complexity of the airway tissue.

Despite the protective effect of mucociliary clearance of the PHAE model, the repeated and long-term exposure to $\mathrm{CeO}_{2}-\mathrm{NPs}$ possibly favored the internalization of relatively high quantities of $\mathrm{CeO}_{2}-\mathrm{NPs}$, collapsing the protective system and giving rise to deleterious effects. Thus, exposures of up to 45 days to 1 to $100 \mu \mathrm{g} / \mathrm{mL}$ of $\mathrm{CeO}_{2} \mathrm{NPs}$ did not induce inflammatory responses in the PHAE model. However between 60 and 75 days of exposure 
to $100 \mu \mathrm{g} / \mathrm{mL}, \mathrm{CeO}_{2}$-NPs induced TNF $\alpha$ and IL- $1 \beta$ responses. TNF $\alpha$ and IL- $1 \beta$ are proinflammatory cytokines that activate the immune system and participate in the acute inflammatory response after exposure to a toxic agent in the pulmonary system [68]. In our study, inflammatory responses were activated after subchronic exposure to $\mathrm{CeO}_{2} \mathrm{NPs}$ and prior to the decrease of plasma membrane integrity and cell viability at day 90 of exposure. As for cell viability and plasma membrane integrity, the late toxic inflammatory response in the PHAE model could be related to the protective effect of mucociliary clearance. The decrease in TNF $\alpha$ and IL-1 $\beta$ levels at day 90 of the exposure should be related to the decrease in cell viability and not due to the return to homeostasis.

Other studies have included long-term exposures (up to one month) of PHAE models to other compounds [61], demonstrating the suitability of this in vitro model as a feasible alternative to reproduce in vivo conditions and pathing the way for longer subchronic in vitro studies. Despite the fact that long-term (two years) $\mathrm{CeO}_{2}-\mathrm{NPs}$ exposures have been already reported in vivo [69], to the best of our knowledge, this is the first time that subchronic toxicity in vitro of $\mathrm{CeO}_{2}$-NPs (up to three months) have been reported. Our study confirmed the usefulness of 3D reconstituted PHAE models for long-term exposures to NPs and has helped to elucidate the subchronic effects of $\mathrm{CeO}_{2}-\mathrm{NPs}$ in the pulmonary epithelium. Additionally, our study has highlighted the importance of assessing the longterm effects of repeated exposure to NPs. As a recommendation for future acute and subchronic toxicity studies, a detailed dose metric analysis [70] should be performed in parallel with the in vitro assays in order to determine the expected delivered dose of NP along the exposure time, thereby corroborating biological findings and helping to support the in vitro to in vivo extrapolation of the data.

\section{Conclusions}

To conclude, acute toxicity assays based on cell lines represent useful tools for highthroughput screening of ENMs. In the case of $\mathrm{CeO}_{2}-\mathrm{NPs}$, sensitive parameters (such as apoptosis-necrosis or ROS levels) are needed to elucidate the underlying mechanisms of toxicity. Nonetheless, the use of physiologically relevant cellular models, such as the reconstituted PHAE models exposed at the ALI to aerosolized NPs, represent a more realistic in vitro approach to studying the cumulative effects of long-term exposure to low doses of airborne contaminants such as $\mathrm{CeO}_{2}$-NPs. Thus, these in vitro systems that better mimic lung tissue and reproduce realistic exposure conditions represent valuable tools for the hazard assessment of NPs. In this particular work, we have shown that $\mathrm{CeO}_{2}-\mathrm{NPs}$ show a reduced toxicity in acute exposure. However, in subchronic exposures cytotoxic and inflammatory responses were observed in the human airway epithelial model after 60 days of exposure to $\mathrm{CeO}_{2}$-NPs. These results suggest that acute toxicity approaches may underestimate the toxicological effect of some ENMs.

Author Contributions: Conceptualization, S.E.M. and F.G.-d.-C.; methodology, A.G.-S., A.K. and E.R.; validation, M.B., M.M.-M., S.E.M. and F.G.-d.-C.; formal analysis, A.G.-S., A.K. and E.R.; writing—original draft preparation, A.G.-S., A.K., and C.A.; writing—review and editing, A.G.-S., A.K., E.R., C.A., M.B. and M.M.-M.; supervision, S.E.M., F.G.-d.-C.; funding acquisition, F.G.-d.-C. All authors have read and agreed to the published version of the manuscript.

Funding: This research was funded by the Basque Government's ELKARTEK programme for collaborative research, grant number KK-2020/00010. The APC was funded by GAIKER Technology Centre.

Institutional Review Board Statement: Not applicable.

Data Availability Statement: The source data underlying Figures are available from the authors upon request.

Acknowledgments: We would like to thank Albiñe Leizea, Amaia Aspiazu, Eneritz Arriaga, and Olatz Suarez for their efforts and technical support during this study.

Conflicts of Interest: The authors declare no conflict of interest. 


\section{References}

1. Huguet-Casquero, A.; Gainza, E.; Pedraz, J.L. Towards green nanoscience: From extraction to nanoformulation. Biotechnol. Adv. 2021, 46, 107657. [CrossRef] [PubMed]

2. Derk, R.; Davidson, D.C.; Manke, A.; Stueckle, T.A.; Rojanasakul, Y.; Wang, L. Potential in vitro model for testing the effect of exposure to nanoparticles on the lung alveolar epithelial barrier. Sens. Bio Sensing Res. 2015, 3, 38-45. [CrossRef] [PubMed]

3. Bayda, S.; Adeel, M.; Tuccinardi, T.; Cordani, M.; Rizzolio, F. The history of nanoscience and nanotechnology: From chemicalphysical applications to nanomedicine. Molecules 2019, 25, 112. [CrossRef] [PubMed]

4. Das, S.S.; Bharadwaj, P.; Bilal, M.; Barani, M.; Rahdar, A.; Taboada, P.; Bungau, S.; Kyzas, G.Z. Stimuli-responsive polymeric nanocarriers for drug delivery, imaging, and theragnosis. Polymers 2020, 12, 1397. [CrossRef]

5. Dimulescu (Nica), I.A.; Nechifor, A.C.; Bărdacă (Urducea), C.; Oprea, O.; Paşcu, D.; Totu, E.E.; Albu, P.C.; Nechifor, G.; Bungău, S.G. Accessible silver-iron oxide nanoparticles as a nanomaterial for supported liquid membranes. Nanomaterials 2021, $11,1204$. [CrossRef]

6. Sabir, F.; Barani, M.; Mukhtar, M.; Rahdar, A.; Cucchiarini, M.; Zafar, M.N.; Behl, T.; Bungau, S. Nanodiagnosis and nanotreatment of cardiovascular diseases: An overview. Chemosensors 2021, 9, 67. [CrossRef]

7. Chandra, H.; Singh, C.; Kumari, P.; Yadav, S.; Mishra, A.P.; Laishevtcev, A.; Brisc, C.; Brisc, M.C.; Munteanu, M.A.; Bungau, S. Promising roles of alternative medicine and plant-based nanotechnology as remedies for urinary tract infections. Molecules 2020, 25, 5593. [CrossRef]

8. Mukhtar, M.; Bilal, M.; Rahdar, A.; Barani, M.; Arshad, R.; Behl, T.; Brisc, C.; Banica, F.; Bungau, S. Nanomaterials for diagnosis and treatment of brain cancer: Recent updates. Chemosensors 2020, 8, 117. [CrossRef]

9. Poh, T.Y.; Ali, N.A.B.M.; Mac Aogáin, M.; Kathawala, M.H.; Setyawati, M.I.; Ng, K.W.; Chotirmall, S.H. Inhaled nanomaterials and the respiratory microbiome: Clinical, immunological and toxicological perspectives. Part. Fibre Toxicol. 2018, 15, 46. [CrossRef]

10. Borm, P.J.A.; Robbins, D.; Haubold, S.; Kuhlbusch, T.; Fissan, H.; Donaldson, K.; Schins, R.; Stone, V.; Kreyling, W.; Lademann, J.; et al. The potential risks of nanomaterials: A review carried out for ECETOC. Part. Fibre Toxicol. 2006, 3, 11. [CrossRef]

11. George, S.; Ho, S.S.; Wong, E.S.P.; Tan, T.T.Y.; Verma, N.K.; Aitken, R.J.; Riediker, M.; Cummings, C.; Yu, L.; Wang, Z.M.; et al. The multi-facets of sustainable nanotechnology-Lessons from a nanosafety symposium. Nanotoxicology 2015, 9, 404-406. [CrossRef]

12. Loret, T.; Peyret, E.; Dubreuil, M.; Aguerre-Chariol, O.; Bressot, C.; le Bihan, O.; Amodeo, T.; Trouiller, B.; Braun, A.; Egles, C.; et al. Air-liquid interface exposure to aerosols of poorly soluble nanomaterials induces different biological activation levels compared to exposure to suspensions. Part. Fibre Toxicol. 2016, 13, 58. [CrossRef]

13. Nowack, B.; Ranville, J.F.; Diamond, S.; Gallego-Urrea, J.A.; Metcalfe, C.; Rose, J.; Horne, N.; Koelmans, A.A.; Klaine, S.J. Potential scenarios for nanomaterial release and subsequent alteration in the environment. Environ. Toxicol. Chem. 2012, 31, 50-59. [CrossRef]

14. Oberdörster, G.; Oberdörster, E.; Oberdörster, J. Nanotoxicology: An emerging discipline evolving from studies of ultrafine particles. Environ. Health Perspect. 2005, 113, 823-839. [CrossRef]

15. Yokel, R.A.; MacPhail, R.C. Engineered nanomaterials: Exposures, hazards, and risk prevention. J. Occup. Med. Toxicol. 2011, 6, 1-27. [CrossRef]

16. Johnston, H.; Pojana, G.; Zuin, S.; Jacobsen, N.R.; Moller, P.; Loft, S.; Semmler-Behnke, M.; McGuiness, C.; Balharry, D.; Marcomini, A.; et al. Engineered nanomaterial risk. Lessons learnt from completed nanotoxicology studies: Potential solutions to current and future challenges. Crit. Rev. Toxicol. 2013, 43, 1-20. [CrossRef]

17. Celardo, I.; De Nicola, M.; Mandoli, C.; Pedersen, J.Z.; Traversa, E.; Ghibelli, L. Ce3+ ions determine redox-dependent antiapoptotic effect of cerium oxide nanoparticles. ACS Nano 2011, 5, 4537-4549. [CrossRef]

18. Pirmohamed, T.; Dowding, J.M.; Singh, S.; Wasserman, B.; Heckert, E.; Karakoti, A.S.; King, J.E.S.; Seal, S.; Self, W.T. Nanoceria exhibit redox state-dependent catalase mimetic activity. Chem. Commun. 2010, 46, 2736-2738. [CrossRef]

19. Zholobak, N.M.; Shcherbakov, A.B.; Bogorad-Kobelska, A.S.; Ivanova, O.S.; Baranchikov, A.Y.; Spivak, N.Y.; Ivanov, V.K. Panthenol-stabilized cerium dioxide nanoparticles for cosmeceutic formulations against ROS-induced and UV-induced damage. J. Photochem. Photobiol. B Biol. 2014, 130, 102-108. [CrossRef]

20. Sajeevan, A.C.; Sajith, V. Diesel engine emission reduction using catalytic nanoparticles: An experimental investigation. J. Eng. (United Kingdom) 2013, 2013. [CrossRef]

21. De Marzi, L.; Monaco, A.; De Lapuente, J.; Ramos, D.; Borras, M.; Di Gioacchino, M.; Santucci, S.; Poma, A. Cytotoxicity and genotoxicity of ceria nanoparticles on different cell lines in vitro. Int. J. Mol. Sci. 2013, 14, 3065-3077. [CrossRef]

22. Chen, J.; Patil, S.; Seal, S.; McGinnis, J.F. Rare earth nanoparticles prevent retinal degeneration induced by intracellular peroxides. Nat. Nanotechnol. 2006, 1, 142-150. [CrossRef]

23. Tisi, A.; Flati, V.; Delle Monache, S.; Lozzi, L.; Passacantando, M.; Maccarone, R. Nanoceria particles are an eligible candidate to prevent age-related macular degeneration by inhibiting retinal pigment epithelium cell death and autophagy alterations. Cells 2020, 9, 1617. [CrossRef]

24. Alpaslan, E.; Geilich, B.M.; Yazici, H.; Webster, T.J. pH-Controlled cerium oxide nanoparticle inhibition of both gram-positive and gram-negative bacteria growth. Sci. Rep. 2017, 7, 45859. [CrossRef]

25. Tsai, D.-S.; Yang, T.-S.; Huang, Y.-S.; Peng, P.-W.; Ou, K.-L. Disinfection effects of undoped and silver-doped ceria powders of nanometer crystallite size. Int. J. Nanomedicine 2016, 11, 2531-2542. [CrossRef] 
26. Mohamed, H.E.A.; Afridi, S.; Khalil, A.T.; Ali, M.; Zohra, T.; Akhtar, R.; Ikram, A.; Shinwari, Z.K.; Maaza, M. Promising antiviral, antimicrobial and therapeutic properties of green nanoceria. Nanomedicine 2020, 15, 467-488. [CrossRef]

27. Xu, C.; Qu, X. Cerium oxide nanoparticle: A remarkably versatile rare earth nanomaterial for biological applications. NPG Asia Mater. 2014, 6, e90. [CrossRef]

28. Park, E.J.; Choi, J.; Park, Y.K.; Park, K. Oxidative stress induced by cerium oxide nanoparticles in cultured BEAS-2B cells Toxicology 2008, 245, 90-100. [CrossRef]

29. Hussain, S.; Al-Nsour, F.; Rice, A.B.; Marshburn, J.; Yingling, B.; Ji, Z.; Zink, J.I.; Walker, N.J.; Garantziotis, S. Cerium dioxide nanoparticles induce apoptosis and autophagy in human peripheral blood monocytes. ACS Nano 2012, 6, 5820-5829. [CrossRef]

30. Cheng, G.; Guo, W.; Han, L.; Chen, E.; Kong, L.; Wang, L.; Ai, W.; Song, N.; Li, H.; Chen, H. Cerium oxide nanoparticles induce cytotoxicity in human hepatoma SMMC-7721 cells via oxidative stress and the activation of MAPK signaling pathways. Toxicol. Vitr. 2013, 27, 1082-1088. [CrossRef]

31. Bessa, M.J.; Brandão, F.; Viana, M.; Gomes, J.F.; Monfort, E.; Cassee, F.R.; Fraga, S.; Teixeira, J.P. Nanoparticle exposure and hazard in the ceramic industry: An overview of potential sources, toxicity and health effects. Environ. Res. 2020, 184, 109297. [CrossRef] [PubMed]

32. Bierkandt, F.S.; Leibrock, L.; Wagener, S.; Laux, P.; Luch, A. The impact of nanomaterial characteristics on inhalation toxicity. Toxicol. Res. 2018, 7, 321-346. [CrossRef] [PubMed]

33. Guo, C.; Robertson, S.; Weber, R.J.M.; Buckley, A.; Warren, J.; Hodgson, A.; Rappoport, J.Z.; Ignatyev, K.; Meldrum, K.; Römer, I.; et al. Pulmonary toxicity of inhaled nano-sized cerium oxide aerosols in Sprague-Dawley rats. Nanotoxicology 2019, 13, 733-750. [CrossRef] [PubMed]

34. Geraets, L.; Oomen, A.G.; Schroeter, J.D.; Coleman, V.A.; Cassee, F.R. Tissue distribution of inhaled micro- and nano-sized cerium oxide particles in rats: Results from a 28-day exposure study. Toxicol. Sci. 2012, 127, 463-473. [CrossRef]

35. Dolez, P.I.; Debia, M. Overview of workplace exposure to nanomaterials. In Nanoengineering: Global Approaches to Health and Safety Issues; Elsevier: Amsterdam, The Netherlands, 2015; pp. 427-484. ISBN 9780444627452.

36. MacArthur Clark, J. The 3Rs in research: A contemporary approach to replacement, reduction and refinement. Br. J. Nutr. 2018, 120, S1-S7. [CrossRef]

37. Ipsos. Public Attitudes to Animal Research in 2018. 2018, pp. 1-36. Available online: https://www.ipsos.com/ipsos-mori (accessed on 12 April 2021).

38. Russell, W.M.S.; Burch, R.L. The Principles of Humane Experimental Technique. Wheathamsted, UK: Universities Federation for Animal Welfare.; Universities Federation for Animal Welfare: Wheathamsted, UK, 1959.

39. Ndika, J.; Ilves, M.; Kooter, I.M.; Gröllers-Mulderij, M.; Duistermaat, E.; Tromp, P.C.; Kuper, F.; Kinaret, P.; Greco, D.; Karisola, P.; et al. Mechanistic Similarities between 3D human bronchial epithelium and mice lung, exposed to copper oxide nanoparticles, support non-animal methods for hazard assessment. Small 2020, 16, 2000527. [CrossRef]

40. Clippinger, A.J.; Ahluwalia, A.; Allen, D.; Bonner, J.C.; Casey, W.; Castranova, V.; David, R.M.; Halappanavar, S.; Hotchkiss, J.A.; Jarabek, A.M.; et al. Expert consensus on an in vitro approach to assess pulmonary fibrogenic potential of aerosolized nanomaterials. Arch. Toxicol. 2016, 90, 1769-1783. [CrossRef]

41. Klein, S.G.; Serchi, T.; Hoffmann, L.; Blömeke, B.; Gutleb, A.C. An improved 3D tetraculture system mimicking the cellular organisation at the alveolar barrier to study the potential toxic effects of particles on the lung. Part. Fibre Toxicol. 2013, 10, 31 [CrossRef]

42. Upadhyay, S.; Palmberg, L. Air-liquid interface: Relevant in vitro models for investigating air pollutant-induced pulmonary toxicity. Toxicol. Sci. 2018, 164, 21-30. [CrossRef]

43. Newland, N.; Baxter, A.; Hewitt, K.; Minet, E. CYP1A1/1B1 and CYP2A6/2A13 activity is conserved in cultures of differentiated primary human tracheobronchial epithelial cells. Toxicol. Vitr. 2011, 25, 922-929. [CrossRef]

44. Reus, A.A.; Maas, W.J.M.; Jansen, H.T.; Constant, S.; Staal, Y.C.M.; van Triel, J.J.; Kuper, C.F. Feasibility of a 3D human airway epithelial model to study respiratory absorption. Toxicol. Vitr. 2014, 28, 258-264. [CrossRef]

45. Epithelix Sárl Epithelix. Innovative In Vitro Solutions for Respiratory Diseases and Chemical Testing. Available online: https: / / www.epithelix.com/ (accessed on 14 April 2021).

46. Baxter, A.; Thain, S.; Banerjee, A.; Haswell, L.; Parmar, A.; Phillips, G.; Minet, E. Targeted omics analyses, and metabolic enzyme activity assays demonstrate maintenance of key mucociliary characteristics in long term cultures of reconstituted human airway epithelia. Toxicol. Vitr. 2015, 29, 864-875. [CrossRef]

47. Meldrum, K.; Robertson, S.B.; Römer, I.; Marczylo, T.; Dean, L.S.N.; Rogers, A.; Gant, T.W.; Smith, R.; Tetley, T.D.; Leonard, M.O. Cerium dioxide nanoparticles exacerbate house dust mite induced type II airway inflammation. Part. Fibre Toxicol. 2018, 15, 24. [CrossRef]

48. Ding, Y.; Weindl, P.; Lenz, A.G.; Mayer, P.; Krebs, T.; Schmid, O. Quartz crystal microbalances (QCM) are suitable for realtime dosimetry in nanotoxicological studies using VITROCELL ${ }^{\circledR}$ Cloud cell exposure systems. Part. Fibre Toxicol. 2020, 17, 44. [CrossRef]

49. Mülhopt, S.; Dilger, M.; Diabaté, S.; Schlager, C.; Krebs, T.; Zimmermann, R.; Buters, J.; Oeder, S.; Wäscher, T.; Weiss, C.; et al. Toxicity testing of combustion aerosols at the air-liquid interface with a self-contained and easy-to-use exposure system. J. Aerosol Sci. 2016, 96, 38-55. [CrossRef] 
50. Czekanska, E.M. Assessment of cell proliferation with resazurin-based fluorescent dye. Methods Mol. Biol. 2011, 740, 27-32. [CrossRef]

51. Diabaté, S.; Armand, L.; Murugadoss, S.; Dilger, M.; Fritsch-Decker, S.; Schlager, C.; Béal, D.; Arnal, M.-E.; Biola-Clier, M.; Ambrose, S.; et al. Air-liquid interface exposure of lung epithelial cells to low doses of nanoparticles to assess pulmonary adverse effects. Nanomaterials 2020, 11, 65. [CrossRef]

52. Monopoli, M.P.; Pitek, A.S.; Lynch, I.; Dawson, K.A. Formation and characterization of the nanoparticle-protein corona. Methods Mol. Biol. 2013, 1025, 137-155. [CrossRef]

53. Panas, A.; Marquardt, C.; Nalcaci, O.; Bockhorn, H.; Baumann, W.; Paur, H.R.; Mülhopt, S.; Diabaté, S.; Weiss, C. Screening of different metal oxide nanoparticles reveals selective toxicity and inflammatory potential of silica nanoparticles in lung epithelial cells and macrophages. Nanotoxicology 2013, 7, 259-273. [CrossRef]

54. Asati, A.; Santra, S.; Kaittanis, C.; Perez, J.M. Surface-charge-dependent cell localization and cytotoxicity of cerium oxide nanoparticles. ACS Nano 2010, 4, 5321-5331. [CrossRef]

55. Hou, J.; Ci, H.; Wang, P.; Wang, C.; Lv, B.; Miao, L.; You, G. Nanoparticle tracking analysis versus dynamic light scattering: Case study on the effect of Ca2+ and alginate on the aggregation of cerium oxide nanoparticles. J. Hazard. Mater. 2018, 360, 319-328. [CrossRef]

56. Lv, B.; Wang, C.; Hou, J.; Wang, P.; Miao, L.; Li, Y.; Ao, Y.; Yang, Y.; You, G.; Xu, Y. Influence of shear forces on the aggregation and sedimentation behavior of cerium dioxide ( $\mathrm{CeO} 2)$ nanoparticles under different hydrochemical conditions. J. Nanoparticle Res. 2016, 18, 1-12. [CrossRef]

57. Gao, Y.; Chen, K.; Ma, J.L.; Gao, F. Cerium oxide nanoparticles in cancer. Onco. Targets. Ther. 2014, 7, 835-840. [CrossRef]

58. Mittal, S.; Pandey, A.K. Cerium oxide nanoparticles induced toxicity in human lung cells: Role of ROS mediated DNA damage and apoptosis. Biomed Res. Int. 2014, 2014, 891934. [CrossRef]

59. Simkó, M.; Mattsson, M.O. Risks from accidental exposures to engineered nanoparticles and neurological health effects: A critical review. Part. Fibre Toxicol. 2010, 7, 42. [CrossRef]

60. Huang, S.; Wiszniewski, L.; Constant, S.; Roggen, E. Potential of in vitro reconstituted 3D human airway epithelia (MucilAir ${ }^{\mathrm{TM}}$ ) to assess respiratory sensitizers. Toxicol. Vitr. 2013, 27, 1151-1156. [CrossRef]

61. Cervena, T.; Vrbova, K.; Rossnerova, A.; Topinka, J.; Rossner, P. Short-term and long-term exposure of the MucilAir ${ }^{\mathrm{TM}}$ model to polycyclic aromatic hydrocarbons. Altern. Lab. Anim. 2019, 47, 9-18. [CrossRef]

62. Leibrock, L.; Jungnickel, H.; Tentschert, J.; Katz, A.; Toman, B.; Petersen, E.; Bierkandt, F.; Singh, A.; Laux, P.; Luch, A. Parametric optimization of an air-liquid interface system for flow-through inhalation exposure to nanoparticles: Assessing dosimetry and intracellular uptake of CeO2 nanoparticles. Nanomaterials 2020, 10, 2369. [CrossRef]

63. Tapparel, C.; Sobo, K.; Constant, S.; Huang, S.; Van Belle, S.; Kaiser, L. Growth and characterization of different human rhinovirus $\mathrm{C}$ types in three-dimensional human airway epithelia reconstituted in vitro. Virology 2013, 446, 1-8. [CrossRef]

64. Rossner, P.; Cervena, T.; Vojtisek-Lom, M.; Vrbova, K.; Ambroz, A.; Novakova, Z.; Elzeinova, F.; Margaryan, H.; Beranek, V.; Pechout, M.; et al. The biological effects of complete gasoline engine emissions exposure in a 3D human airway model (MucilAirTM) and in human bronchial epithelial cells (BEAS-2B). Int. J. Mol. Sci. 2019, 20, 5710. [CrossRef]

65. Mercier, C.; Jacqueroux, E.; He, Z.; Hodin, S.; Constant, S.; Perek, N.; Boudard, D.; Delavenne, X. Pharmacological characterization of the 3D MucilAir ${ }^{\mathrm{TM}}$ nasal model. Eur. J. Pharm. Biopharm. 2019, 139, 186-196. [CrossRef] [PubMed]

66. Furubayashi, T.; Inoue, D.; Nishiyama, N.; Tanaka, A.; Yutani, R.; Kimura, S.; Katsumi, H.; Yamamoto, A.; Sakane, T. Comparison of various cell lines and three-dimensional mucociliary tissue model systems to estimate drug permeability using an in vitro transport study to predict nasal drug absorption in rats. Pharmaceutics 2020, 12, 79. [CrossRef] [PubMed]

67. Kooter, I.M.; Grollers-Mulderij, M.; Steenhof, M.; Duistermaat, E.; van Acker, F.; Staal, Y.; Schoen, E.; Stierum, R.; Pellis, L.; Kuper, F. Cerium Oxide Nanoparticles Air Exposure: A Comparison Study Using a Human 3D Airway Model and A549 and Beas-2B Cell Lines. 2014. Available online: https:/ / www.vitrocell.com/portals/0/news/publications/SOT-2014-poster-cerium-tno.pdf (accessed on 8 June 2021).

68. Moldoveanu, B.; Otmishi, P.; Jani, P.; Walker, J.; Sarmiento, X.; Guardiola, J.; Saad, M.; Yu, J. Inflammatory mechanisms in the lung. J. Inflamm. Res. 2008, 2, 1. [CrossRef] [PubMed]

69. Tentschert, J.; Laux, P.; Jungnickel, H.; Brunner, J.; Estrela-Lopis, I.; Merker, C.; Meijer, J.; Ernst, H.; Ma-Hock, L.; Keller, J.; et al. Organ burden of inhaled nanoceria in a 2-year low-dose exposure study: Dump or depot? Nanotoxicology 2020, 14, 554-576. [CrossRef]

70. DeLoid, G.M.; Cohen, J.M.; Pyrgiotakis, G.; Demokritou, P. Preparation, characterization, and in vitro dosimetry of dispersed, engineered nanomaterials. Nat. Protoc. 2017, 12, 355-371. [CrossRef] 